\title{
Wet deposition in the remote western and central Mediterranean as a source of trace metals to surface seawater
}

\author{
Karine Desboeufs ${ }^{1}$, Franck Fu ${ }^{1}$, Matthieu Bressac ${ }^{2,3}$, Antonio Tovar-Sánchez ${ }^{4}$, Sylvain Triquet ${ }^{1}$, \\ Jean-François Doussin $^{5}$, Chiara Giorio ${ }^{6,7}$, Patrick Chazette $^{8}$, Julie Disnaquet ${ }^{9}, 10$, Anaïs Feron ${ }^{1}$, \\ Paola Formenti ${ }^{1}$, Franck Maisonneuve ${ }^{5}$, Araceli Rodríguez-Romero ${ }^{4}$, Pascal Zapf ${ }^{5}$, François Dulac ${ }^{8}$, \\ and Cécile Guieu ${ }^{3}$ \\ ${ }^{1}$ Université de Paris and Univ Paris Est Creteil, CNRS, LISA, UMR 7583, 75013 Paris, France \\ ${ }^{2}$ Institute for Marine and Antarctic Studies, University of Tasmania, Hobart, Tasmania, Australia \\ ${ }^{3}$ Sorbonne Université, CNRS, Laboratoire d'Océanographie de Villefranche, LOV, \\ 06230 Villefranche-sur-Mer, France \\ ${ }^{4}$ Department of Ecology and Coastal Management, Institute of Marine Sciences of Andalusia (CSIC), \\ 11510 Puerto Real, Cádiz, Spain \\ ${ }^{5}$ Univ Paris Est Creteil and Université de Paris, CNRS, LISA, UMR 7583, 94010 Créteil, France \\ ${ }^{6}$ Laboratoire de Chimie de l'Environnement (LCE), UMR 7376 CNRS, \\ Aix-Marseille Université, 13331 Marseille, France \\ ${ }^{7}$ Yusuf Hamied Department of Chemistry, University of Cambridge, Lensfield Road, \\ CB2 1EW, Cambridge, United Kingdom \\ ${ }^{8}$ Laboratoire des Sciences du Climat et de l'Environnement (LSCE), UMR 8212 CEA-CNRS-UVSQ, \\ Institut Pierre-Simon Laplace, Univ. Paris-Saclay, 91191 Gif-sur-Yvette, France \\ ${ }^{9}$ Marine Biology Research Division, Scripps Institution of Oceanography, UCSD, La Jolla, CA 92037, USA \\ ${ }^{10}$ Sorbonne Université, CNRS, Laboratoire d'Océanographie Microbienne, LOMIC, \\ 66650 Banyuls-sur-Mer, France
}

Correspondence: Karine Desboeufs (karine.desboeufs@lisa.ipsl.fr)

Received: 22 July 2021 - Discussion started: 25 August 2021

Revised: 12 January 2022 - Accepted: 16 January 2022 - Published: 18 February 2022

\begin{abstract}
This study reports the only recent characterization of two contrasted wet deposition events collected during the PEACETIME (ProcEss studies at the Air-sEa Interface after dust deposition in the MEditerranean Sea) cruise in the open Mediterranean Sea (Med Sea) and their impact on trace metal (TM) marine stocks. Rain samples were analysed for $\mathrm{Al}, 12 \mathrm{TMs}(\mathrm{Co}, \mathrm{Cd}, \mathrm{Cr}, \mathrm{Cu}, \mathrm{Fe}, \mathrm{Mn}, \mathrm{Mo}, \mathrm{Ni}, \mathrm{Pb}, \mathrm{Ti}, \mathrm{V}$ and $\mathrm{Zn}$ ) and nutrient (N, $\mathrm{P}$, dissolved organic carbon) concentrations. The first rain sample collected in the Ionian Sea (Rain ION) was a typical regional background wet deposition event, whereas the second rain sample collected in the Algerian Basin (Rain FAST) was a Saharan dust wet deposition event. Even in the remote Med Sea, all background TM inputs presented an anthropogenic signature, except for Fe, Mn and Ti. The concentrations of TMs in the two rain samples were significantly lower compared to concentrations in rains collected at coastal sites reported in the literature, due to the decrease in anthropogenic emissions during the preceding decades. The atmospheric TM inputs were mainly dissolved forms, even in dusty Rain FAST. The TM stocks in the mixed layer (ML, 0-20 m) at the FAST station before and after the event showed that the atmospheric inputs were a significant supply of particulate TMs and dissolved Fe and Co for surface seawater. Even if the wet deposition delivers TMs mainly in soluble form, the post-deposition aerosol dissolution could to be a key additional pathway in the supply of dissolved TMs. At the scale of the western and central Mediterranean, the atmospheric inputs were of the same order of magnitude as ML stocks for dissolved $\mathrm{Fe}, \mathrm{Co}$ and $\mathrm{Zn}$, highlighting the role of the atmosphere in their
\end{abstract}


biogeochemical cycles in the stratified Med Sea. In case of intense dust-rich wet deposition events, the role of atmospheric inputs as an external source was extended to dissolved $\mathrm{Co}, \mathrm{Fe}, \mathrm{Mn}, \mathrm{Pb}$ and $\mathrm{Zn}$. Our results suggest that the wet deposition constitutes only a source of some of dissolved TMs for Med Sea surface waters. The contribution of dry deposition to the atmospheric TM inputs needs to be investigated.

\section{Introduction}

Atmospheric deposition of continental aerosol has long been recognized to influence trace element concentrations in remote oceanic surface waters (Buat-Ménard and Chesselet, 1979; Hardy, 1982; Buat-Ménard, 1983). In particular, the Mediterranean Sea (Med Sea) is an oligotrophic environment of nutrient-limited marine microbial growth during the long Mediterranean summer season, which is characterized by a strong thermal stratification of surface waters (The Mermex Group, 2011). The Mediterranean atmosphere is characterized by the permanent presence of anthropogenic aerosols from industrial and domestic activities around the basin (e.g. Sciare et al., 2003; Kanakidou et al., 2011). In addition to this anthropogenic background, the Mediterranean Basin is also subject to seasonal contributions of particles from biomass fires in summer (Guieu et al., 2005) and to intense sporadic Saharan dust inputs (e.g. Loÿe-Pilot and Martin, 1996; Vincent et al., 2016). Several studies have emphasized that the atmospheric deposition of aerosols, notably through wet deposition, plays a significant role in the marine cycles of nutrients, such as nitrogen $(\mathrm{N})$ and phosphorus $(\mathrm{P})$ (e.g. PulidoVillena et al., 2010; Richon et al., 2018a, b; Violaki et al., 2018), and micronutrients, such as iron (Fe) (Bonnet and Guieu, 2006). Recently, atmospheric dust inputs were identified to have a fertilizing effect on planktonic stocks and fluxes, even in the presence of relatively high dissolved $\mathrm{N}$, $\mathrm{P}$ and $\mathrm{Fe}$ concentrations (Ridame et al., 2011; reviewed in Guieu and Ridame, 2022). Mackey et al. (2012) showed that trace metals (TMs) provided by dust deposition could explain this fertilizing effect. Indeed, many TMs, including Mn, Co, $\mathrm{Ni}$ (Mackey et al., 2012), $\mathrm{Cu}$ (Annett et al., 2008) and $\mathrm{Zn}$ (Morel et al., 1991), play physiological roles for phytoplanktonic organisms. These TMs are present in very low concentrations in oligotrophic systems such as the Med Sea, possibly limiting (or co-limiting) phytoplankton growth (PinedoGonzàles et al., 2015) and pointing to the importance of dust deposition as a source of TMs for planktonic communities. On the other hand, atmospheric deposition of European aerosols was identified to have a negative effect on chlorophyll concentrations (Gallisai et al., 2014) by providing $\mathrm{Cu}$ at toxic levels (Jordi et al., 2012).

The atmospheric deposition of TMs in the Mediterranean is related to both dust and anthropogenic aerosol deposition (Desboeufs et al., 2018). The role of dust deposition as a source of TMs was observed from the correlation between the atmospheric deposition of mineral dust and the enrich- ment of dissolved TMs $(\mathrm{Cd}, \mathrm{Co}, \mathrm{Cu}, \mathrm{Fe})$ in the Med Sea surface microlayer (SML) (Tovar-Sánchez et al., 2014). For the water column, the adding of dissolved Fe and Mn was emphasized in mesocosm experiments after dust addition mimicking intense wet dust deposition (Wuttig et al., 2013). Baconnais et al. (2019) showed that the dissolved $\mathrm{Cu}$ isotope signature in surface waters could be related to Saharan dust deposition in the southern Med Sea. By comparison based on annual or monthly deposition measurements and marine concentrations, the potential role of atmospheric deposition as source of dissolved $\mathrm{Co}$ and $\mathrm{Fe}$ for Mediterranean surface waters was also pointed out (Bonnet and Guieu, 2006; Dulaquais et al., 2017). Due to sporadic and intense Mediterranean storms, scavenging air masses loaded with anthropogenic aerosols or Saharan dust could lead to higher TM deposition fluxes by rain than dry deposition (Desboeufs, 2022). Moreover, even if annual wet and dry deposition are equivalent in the Mediterranean (Theodosi et al., 2010), wet deposition is known to provide dissolved and potentially bioavailable forms of TMs (Jickells et al., 2016). Yet, to the best of our knowledge, the direct impact of wet deposition on TM concentrations in surface seawater has not been studied at same location by concurrently collecting both rainwater and seawater samples before this work (either in the Med Sea or in other oceanic regions).

Two key criteria used to assess the potential impact of TMs and nutrients are their respective concentrations (or fluxes) and fractional solubility (hereafter referred to as solubility), i.e. the partitioning between dissolved and total concentrations in rainwater. Indeed, the dissolved fraction of nutrients and TMs is considered a surrogate for their bioavailability (Jickells et al., 2016). The following studies have reported concentrations of TMs in rainwater samples collected around the Mediterranean Basin: Al-Momani et al. (1998), Kanellopoulou, (2001), and Özsoy and Örnektekin, (2009) in the eastern basin and Losno (1989), Guieu et al. (1997), Frau et al. (1996), Chester et al. (1997) and Guerzoni et al. (1999) in the western basin. These studies led to highly variable TM concentrations and solubilities, illustrating the large variability of TM inputs during wet deposition events in the Med Sea (reviewed in Desboeufs, 2022). All of these studies were performed at coastal sites. Offshore samples of rainwater have rarely been reported in the literature. In the Mediterranean, to our knowledge, only trace element concentrations from three rain samples collected at sea in April 1981 have been reported in a PhD thesis (Dulac, 1986). However, due to the continental and local sources of pollution, the variety 
of anthropogenic aerosol sources (Amato et al., 2016), and the physico-chemical processes during atmospheric aerosol transport (chemical ageing, dispersion, gravitational settling, in-cloud reactivity) (Weinzierl et al., 2017), the TM rain composition of the coastal zone may not be representative of atmospheric deposition to the remote Mediterranean.

The PEACETIME cruise (ProcEss studies at the Air-sEa Interface after dust deposition in the MEditerranean Sea) performed in spring 2017 aimed to study the impacts of atmospheric deposition, in particular Saharan dust events, on the physical, chemical and biological processes in this marine oligotrophic environment (Guieu et al., 2020a). We investigated the concentration and solubility of TMs and nutrients from two rain events sampled in the central and western Med Sea during the cruise. We compared our results with the existing literature on TM concentrations in offshore and coastal rain samples dating from the 1990s to investigate the time evolution of TM concentrations and potential differences with the open sea. Additionally, to assess the impact of wet deposition on the surface TM concentrations, surface seawater and rainwater were concurrently collected. This is the first time TM data for these atmospheric and marine compartments in the Med Sea have all been discussed at the same time and in the same place.

\section{Sampling and methods}

\subsection{Sampling and chemical analysis of rainwater}

The PEACETIME oceanographic campaign (https://doi.org/10.17600/17000300, Guieu et al., 2020b) took place in the western and central Med Sea on board the French R/V Pourquoi Pas? between 11 May and 10 June 2017, i.e. at the beginning of the Mediterranean stratification season (Guieu et al., 2020a). The rain collector was installed on the upper deck ( $22 \mathrm{~m}$ above sea level) where no on-board activities were taking place to avoid contamination. The rain collector was equipped with an online filtration system to separate the dissolved and particulate fractions at the time of collection (details of the filtration system are available in Heimburger et al., 2012), allowing for the calculation of solubility of TMs in the rainwater. The filtration device was equipped with a Nuclepore ${ }^{\circledR}$ polycarbonate membrane filter (porosity: $0.2 \mu \mathrm{m}$; diameter: $47 \mathrm{~mm}$ ). The diameter of the funnel of the collector was $24 \mathrm{~cm}$. The rain collector was installed only when rain was expected and was covered by an acid-washed sealed plastic film when not in use. All the sampling materials were thoroughly acid-washed in the laboratory prior to the cruise departure (the washing protocol is described in Heimburger et al., 2012). No stabilizing device was used to keep the funnel level during the pitch and roll of the ship, preventing a precise assessment of the height of rainfall from the collected water volume. During the rain sampling, the $\mathrm{R} / \mathrm{V}$ was always facing the wind to avoid contamination by the ship's exhaust, as the chimney was situated on the lower deck and behind the collector.

Immediately after sampling, the collector was disassembled under a laminar flow hood inside an on-board cleanroom laboratory. The dissolved fraction was separated into four aliquots dedicated to (i) TM determination using inductively coupled plasma-coupled (ICP) methods, (ii) major ion analysis by ion chromatography (IC), (iii) dissolved organic carbon (DOC) determination by high-temperature catalytic oxidation (HTCO) on a Shimadzu total organic carbon analyser (as described in Van Wambeke et al., 2021a) and (iv) pH measurement. For ICP measurements, the sample was acidified immediately to $1 \%$ by volume of ultra-pure nitric acid $\left(\mathrm{HNO}_{3} 67 \%-69 \%\right.$, Ultrapur, Normatom ${ }^{\circledR}$, VWR). For IC analysis, the filtrate was immediately frozen. For DOC analysis, the filtrate was collected into pre-combusted glass ampoule and acidified to $\mathrm{pH} 2$ with phosphoric acid. The ampoule was immediately sealed and stored in the dark at room temperature.

The filter (particulate fraction) was dried under the laminar flow hood and then put in a storage box and packed with a plastic bag to avoid contamination. After returning to the laboratory, filters were acid-digested by using the protocol adapted from Heimburger et al. (2012) as follows: filters were placed in tightly capped Savillex ${ }^{\mathrm{TM}}$ PFA digestion vessels with $4 \mathrm{~mL}$ of a mixture of $\mathrm{HNO}_{3}(67 \%-69 \%$, Ultrapur, Normatom ${ }^{\circledR}$, VWR), $\mathrm{H}_{2} \mathrm{O}$ and hydrofluoric (HF) acids $\left(40 \%\right.$, Ultrapur, Normatom ${ }^{\circledR}$, VWR) at a ratio of $3: 1: 0.5$ and then heated in an oven at $130^{\circ} \mathrm{C}$ for $14 \mathrm{~h}$. After cooling, the acid solution was completely evaporated on a heater plate (ANALAB, 250, A4) at $140{ }^{\circ} \mathrm{C}$ for about $2 \mathrm{~h}$, and thereafter $0.5 \mathrm{~mL}$ of $\mathrm{H}_{2} \mathrm{O}_{2}\left(30 \%-32 \%\right.$, Romil-UpA $\left.{ }^{\mathrm{TM}}\right)$ and $1 \mathrm{~mL}$ of the acidified water $\left(2 \% \mathrm{HNO}_{3}\right)$ was added to the vessels and heated for $30 \mathrm{~min}$ to dissolve the dry residue in the bottom of the vessels. Finally, $12 \mathrm{~mL}$ of acidified water $\left(1 \% \mathrm{HNO}_{3}\right)$ was added to obtain $13.5 \mathrm{~mL}$ of solution in a tube for ICP analyses.

The dissolved fractions and the solutions issued from digestion of the particulate fractions were analysed by ICPAES (inductively coupled plasma atomic emission spectrometry, Spectro ARCOS Ametek ${ }^{\circledR}$, Desboeufs et al., 2014) for major elements (Al, $\mathrm{Ca}, \mathrm{K}, \mathrm{Mg}, \mathrm{Na}, \mathrm{S}$ ) and by HR-ICP-MS (high-resolution inductively coupled plasma mass spectrometry, Neptune Plus ${ }^{\mathrm{TM}}$ at Thermo Scientific ${ }^{\mathrm{TM}}$ ) for $\mathrm{P}$ and the following TMs: $\mathrm{Cd}, \mathrm{Co}, \mathrm{Cr}, \mathrm{Cu}, \mathrm{Fe}, \mathrm{Mn}, \mathrm{Mo}, \mathrm{Ni}, \mathrm{Pb}, \mathrm{Ti}$, $\mathrm{V}$ and $\mathrm{Zn}$. The dissolved fraction was analysed by IC (IC 850 Metrohm) for the inorganic and organic anions $\left(\mathrm{NO}_{2}^{-}\right.$, $\mathrm{NO}_{3}^{-}, \mathrm{PO}_{4}^{3-}, \mathrm{SO}_{4}^{2-}, \mathrm{F}^{-}, \mathrm{Cl}^{-}, \mathrm{Br}^{-}, \mathrm{HCOO}^{-}, \mathrm{CH}_{3} \mathrm{COO}^{-}$, $\mathrm{C}_{2} \mathrm{H}_{5} \mathrm{COO}^{-}$, MSA, $\mathrm{C}_{2} \mathrm{O}_{4}^{2-}$ ) and for the cation $\mathrm{NH}_{4}^{+}$(Mallet et al., 2019). Only TMs, major nutrients (i.e. $\mathrm{N}$ and $\mathrm{P}$ species) and $\mathrm{Al}$ are discussed in this paper. The speciation of dissolved $\mathrm{P}$ was estimated by determining dissolved inorganic phosphorus (DIP) from phosphate concentrations expressed as $\mathrm{P}$, and the dissolved organic phosphorus (DOP) was deter- 
mined from the difference between total dissolved phosphorus (TDP), obtained by HR-ICP-MS, and DIP, obtained by IC. Dissolved inorganic nitrogen (DIN) was defined as the sum of $\mathrm{NO}_{2}^{-}, \mathrm{NO}_{3}^{-}$and $\mathrm{NH}_{4}^{+}$and was expressed as $\mathrm{N}$.

In order to estimate the contamination of sampling and analytical protocols, three blanks of rain samples that were collected on board during the cruise were used and processed. Blank samples were prepared by rinsing the funnel with $150 \mathrm{~mL}$ of ultrapure water $(18.2 \mathrm{~m} \Omega \mathrm{cm})$ with the same protocol of rain collection. The procedural limit of detection (LoD) was defined as 3 times the standard deviation of blank samples both for dissolved and particulate fractions estimated after acid digestion. All dissolved and particulate sample concentrations were higher than the LoD, except for $\mathrm{NO}_{2}^{-}$in the two rain samples. The blank concentrations represented $10.2 \%$ on average for TMs and were typically lower than $20 \%$ of the sample concentrations, except for $\mathrm{Cd}(52 \%)$ and Mo $(43 \%)$ in the dissolved fraction. Blank concentrations were subtracted from all sample concentrations.

\subsection{Atmospheric ancillary measurements}

The PEGASUS (PortablE Gas and Aerosol Sampling UnitS, https://www.pegasus.cnrs.fr/, last acess: 11 February 2022) mobile platform of LISA is a self-contained facility based on two standard $20 \mathrm{ft}(121.16 \mathrm{~m})$ containers that are adapted with air-conditioning, rectified power, air intake, and exhausts for sampling and online measurements of atmospheric aerosols and gaseous compounds and their analysis (Formenti et al., 2019). During the PEACETIME cruise, only the sampling module of the facility was deployed on the starboard side of deck 7 of the R/V. The PEGASUS instrumental payload of relevance to this paper included measurements of the major gases such as $\mathrm{NO}_{x}, \mathrm{SO}_{2}, \mathrm{O}_{3}$ and $\mathrm{CO}$ by online analysers (Horiba APNA, APSA, APOA and PICARRO, respectively; 2 min resolution, with a detection limit of $1 \mathrm{ppb}$ for $\mathrm{CO}$ and 0.5 for all other gases). These gases were used to estimate the origins of sampled air.

From the first of June 2017 (the device was not operational before this date), additional measurements by an ALS450 ${ }^{\circledR}$ Rayleigh-Mie lidar (Leosphere ${ }^{\mathrm{TM}}$; Royer et al., 2011) were used to monitor the vertical distribution of aerosols over time and the associated integrated columns. The vertical lidar profiles were analysed to yield the apparent backscatter coefficient $(\mathrm{ABC})$ corrected from the molecular transmission, as well as the volume depolarization ratio (VDR). The inversion procedure (Chazette et al., 2016, 2019) to retrieve the aerosol extinction coefficient (unit km-1) used a verticaldependent lidar ratio that took into account two aerosol layers. The first layer corresponded to marine aerosols in the marine boundary layer (MBL), and the second layer corresponded to a desert aerosol layer that could extend between $\sim 1$ and $6 \mathrm{~km}$ above mean sea level (a.m.s.l.). In accordance with Chazette et al. (2016), who worked at the same wavelength and in the same region, the lidar ratios were set to
25 and $55 \mathrm{sr}$ for the first and second layer, respectively. The vertical profile of the aerosol extinction coefficient was retrieved from $0.2 \mathrm{~km}$ a.m.s.l. upwards with a vertical resolution of $15 \mathrm{~m}$. Based on these profiles, the integrated column content of dust aerosols was estimated using a specific extinction cross section of $1.1 \mathrm{~m}^{2} \mathrm{~g}^{-1}$ as proposed by Raut and Chazette (2009).

In addition, detailed meteorological data such as air and sea temperature, atmospheric pressure, relative humidity, atmospheric pressure, heat flux, and wind speed and direction were provided on a $30 \mathrm{~s}$ time step basis by the ship's permanent instrumentation.

\subsection{Sampling and analysis of dissolved TMs in seawater}

TM samples were also collected in the water column using a titanium trace metals clean (TMC) rosette (mounted with 24 teflon-coated Go-Flo bottles) before and after the rain event (Bressac et al., 2021). Although rosette deployments were performed over the whole water column, we focus here on the $0-20 \mathrm{~m}$ marine mixed layer (ML). Immediately after recovery, the Go-Flo bottles were transferred inside a Class 100 clean laboratory container. Seawater samples were directly filtered from the bottles through acid-cleaned $0.2 \mu \mathrm{m}$ capsule filters (Sartorius Sartobran P capsule 0.45 and $0.2 \mu \mathrm{m}$ ). All samples were acidified on board to $\mathrm{pH}<2$ with Ultrapuregrade $\mathrm{HCl}$ under a Class $100 \mathrm{HEPA}$ laminar flow hood. Metals (namely $\mathrm{Cd}, \mathrm{Co}, \mathrm{Cu}, \mathrm{Ni}, \mathrm{Mo}, \mathrm{V}, \mathrm{Zn}$ and $\mathrm{Pb}$ ) were preconcentrated using an organic extraction method (Bruland et al., 1979) and quantified by ICP-MS (Perkin Elmer ELAN DRC-e) in the home laboratory. The accuracy of the preconcentration method and analysis for TMs was established using seawater reference material (CASS 6, NRC-CNRC) with recoveries ranging from $89 \%$ for Mo to $108 \%$ for $\mathrm{Pb}$. Due to the complexity of the analytical method, all the TMC samplings were not analysed for $\mathrm{Cd}, \mathrm{Co}, \mathrm{Cu}, \mathrm{Ni}, \mathrm{Mo}, \mathrm{V}$, $\mathrm{Zn}$ and $\mathrm{Pb}$. Overall, one or two depths were obtained in the mixed layer $(0-20 \mathrm{~m})$. Dissolved $\mathrm{Fe}$ and $\mathrm{Al}$ concentrations were also measured on board. Dissolved Fe concentrations were measured using an automated flow injection analysis (FIA) with online preconcentration and chemiluminescence detection (Bonnet and Guieu, 2006), and dissolved Al concentrations were measured using the fluorometric method described by Hydes and Liss (1976). Sampling and analysis for dissolved $\mathrm{Fe}$ and $\mathrm{Al}$ concentrations are fully described in Bressac et al. (2021) and covered at least four depths in the $0-20 \mathrm{~m}$ mixed layer.

\subsection{Concurrent sampling strategy}

Our sampling strategy of collecting seawater before and after rains was chosen to trace the fate of atmospheric TMs and nutrients in the water column after wet deposition events in an open ocean. The sampling time resolution was optimized to obtain results before and after rains; however, this strategy 
was very dependent on meteorological conditions. The time chart of the sampling of rain and surface water is presented in Fig. 1.

The potential enrichment of the ML was estimated by comparing atmospheric wet deposition fluxes and marine stocks in particulate and dissolved fraction and by calculating the difference (delta) in TM stocks before and after rain. Due to the long time (48 h) between ML27 and ML29, and hence the possible change of water masses between the two samplings, it was excluded to obtain reliable background concentration levels. As a consequence, the enrichment of the ML was not calculated for the Ionian Sea (ION) station. Dust rain deposition over the Algerian Basin (FAST) station area started on 3 June (see Sect. 3.1). Bressac et al. (2021) showed that the dust signature, traced by changes in $\mathrm{Al}$ and Fe particulate stocks in the ML, was already visible from the ML03 sampling but not for dissolved stocks. However, they also presumed that the water mass sampled before deposition (ML02) was different from the one sampled during the rest of the time series (ML03 to ML06) but was representative of particulate background level. As a consequence, we defined the enrichment of the ML as the difference between the stocks after rains (ML05+4) and the initial seawater stocks, i.e. ML02 for particulate stocks (before dust signature) and ML04 for dissolved stocks (the closest sampling before the rain).

\subsection{Enrichment factor and solubility}

In order to better constrain the origin of TMs in the rain samples, their enrichment factors (EFs; Rahn, 1976) relative to the Earth's crust were calculated based on their total concentrations (dissolved + particulate fractions) as follows:

$\mathrm{EF}=\frac{([X] /[\mathrm{Al}]) \text { sample }}{([X] /[\mathrm{Al}]) \mathrm{crust}}$,

where $[X] /[\mathrm{Al}]$ is the ratio between an element $X$ and $\mathrm{Al}$ concentrations in rainwater samples (at the numerator) and in the upper continental crust (denominator) from Rudnick and Gao (2003). Aluminium is currently used as a reference element as it predominantly has a crustal origin. For a given TM, EF > 1 indicates an enrichment with respect to the average composition of the Earth's crust. To account for the soil composition variability of mineral dust sources, TMs with an EF value $>10$ are considered significantly enriched, which points to a non-crustal source (Rahn, 1976). For most metals, enrichment shows important input from anthropogenic sources, due to their low content in other non-crustal sources such as sea spray or biogenic aerosols (Jickells et al., 2016).

The fractional solubility of TMs in the two rainwater events was calculated as follows:

$S_{X} \%=\frac{[X] \text { dissolved }}{[X] \text { total }} \times 100$, where $S_{X} \%$ is the solubility (in $\%$ ) of an element $X$ in the rainwater and $[X]_{\text {dissolved }}$ and $[X]_{\text {total }}$ are its soluble and total concentration, respectively.

\subsection{Atmospheric wet deposition fluxes}

Impacts on biogeochemical cycles and ecosystem functioning following a rain event occur on timescales of a few days (2-3) and space scales of tens of kilometres (about 20-50 km within the radius of the $\mathrm{R} / \mathrm{V}$ position). In the specific context of oceanographic cruising, the documentation of these impacts is restricted to the vertical dimension at the prescribed temporal scale. In this vertical dimension, the exchange of TMs into the ML was controlled both by atmospheric inputs over the R/V position and by advection from surrounding water masses that may have been impacted by surrounding rainfall. Therefore, we had to consider this process in our estimation of the atmospheric flux contributions. For this purpose, the atmospheric fluxes have to be integrated to the extent of the rain area that can impact the marine surface layers. We derived wet deposition fluxes by considering the total precipitation accumulated during the duration of the rain over the area around the $\mathrm{R} / \mathrm{V}$ position (in a radius of $\sim 25 \mathrm{~km}$ ). Thus, the wet deposition fluxes were calculated by multiplying the TM concentrations $\left(\mu \mathrm{g} \mathrm{L}^{-1}\right.$ or $\left.\mu \mathrm{molL}^{-1}\right)$ in our rain samples by the total precipitation $(\mathrm{mm})$ in this area. The total precipitation of the rain events was issued from the hourly total precipitation accumulated during the rain events over the region from ERA5 ECMWF reanalysis (Hersbach et al., 2018) and (where possible) from the rain rate composite radar products from the European OPERA database (Saltikoff et al., 2019). Although subject to uncertainties (Morin et al., 2003), a surface-based weather radar is probably the best tool to estimate rainfall in the surroundings of the $\mathrm{R} / \mathrm{V}$ since this method is a direct measurement of precipitation with both the best time and spatial resolution in comparison to model estimations. However, the OPERA database does not include Italian radars, which did not cover the central area of the Ionian Sea during the cruise anyway. ERA5 data were available on regular latitude-longitude grids at $0.25^{\circ} \times 0.25^{\circ}$ resolution. The accumulated precipitation was taken from the grid points spanning the $\mathrm{R} / \mathrm{V}$ location, i.e. $\pm 0.25^{\circ}$ around the central grid point, to integrate the regional variability. Surface rain rate radar composite images were available every $15 \mathrm{~min}$ with a spatial resolution of $2 \mathrm{~km} \times 2 \mathrm{~km}$. The accumulated precipitation was the sum of integrated rain rates during the rain duration averaged over the radar pixels spanning the $\mathrm{R} / \mathrm{V}$ location within a radius of about $25 \mathrm{~km}$.

\subsection{Stocks in the surface seawater}

The trace metal stocks within the ML were calculated by trapezoidal integrations of marine concentrations from TMC rosette samplings. The upper water column was stratified along the cruise transect (Taillandier et al., 2020), with a 


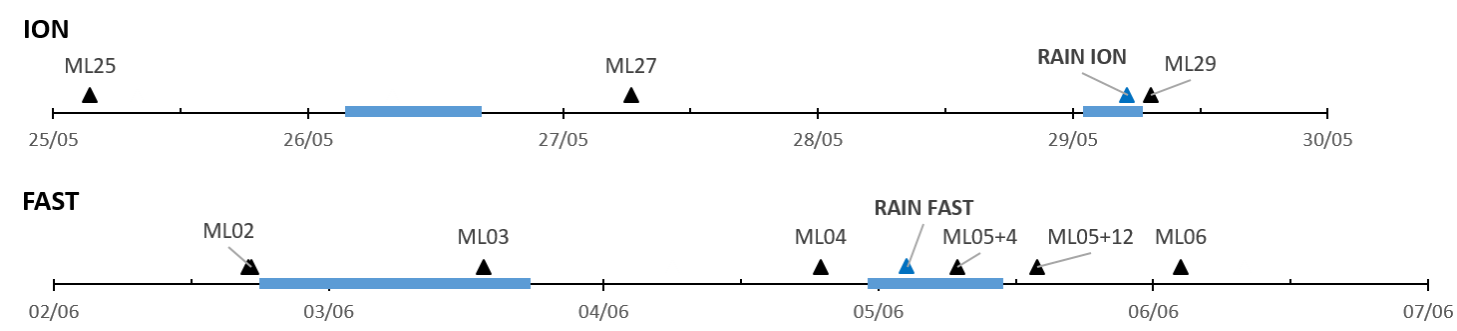

Figure 1. Sampling chronology during the ION and FAST stations for the ML and rains. The blue periods correspond to rainfall in the vicinity of the R/V position (from ERA 5 reanalysis and radar imagery; see Sect. 3.1.), and blue triangles correspond to the rainfall on the R/V position. Samplings were performed $4 \mathrm{~d}$ (ML25) and $2 \mathrm{~d}$ (ML27) before and $2 \mathrm{~h}$ (ML29) after Rain ION and at a higher frequency at FAST, i.e. 57 (ML02), 37 (ML03) and 7.5 (ML04) hours before and 4.5 (ML05+4), 12 (ML05+12), and 24h (ML06) after Rain FAST.

mixed-layer depth (MLD) ranging from 7 to $21 \mathrm{~m}$ (11 to $21 \mathrm{~m}$ at ION and 11 to $19 \mathrm{~m}$ at FAST (Van Wambeke et al., 2021b). The MLD fluctuations, for example due to wind peaks associated with rain events, could create rapidly changing conditions of vertical advection from deeper waters. However, with no significant increase in TM concentrations being observed below the ML down to about $50 \mathrm{~m}$ (not shown), the enrichment observed in the ML after rain could not be attributed to any mixing with deeper water due to high wind. As a consequence, stocks in the ML have been integrated over a constant depth range of 0-20 $\mathrm{m}$ for comparison, in accordance with Bressac et al. (2021). For $\mathrm{Cu}, \mathrm{Fe}, \mathrm{Ni}$, and $\mathrm{Zn}$ stocks were estimated for both the dissolved and particulate fractions in the $\mathrm{ML}$; for $\mathrm{Co}, \mathrm{Cd}, \mathrm{Mo}, \mathrm{Pb}$, and $\mathrm{V}$ for the dissolved fraction only (particulate fraction was not analysed); and for $\mathrm{Mn}$ and $\mathrm{Ti}$ for the particulate fraction only. The particulate and dissolved fractions of TM stock or fluxes will be referred to as PTM and dTM, respectively.

The partitioning coefficient between the particulate and dissolved phases $(\mathrm{Kd}=$ [particulate]/[dissolved]) was used to investigate exchange between the dissolved and particulate pools of TMs.

\section{Results}

\subsection{Atmospheric conditions during wet deposition events}

The general meteorological conditions during the cruise indicated that the ION and FAST stations were highly affected by cloudy weather conditions. During these periods, two significant rain events occurred over the $\mathrm{R} / \mathrm{V}$ position and were sampled. The first sample (Rain ION) was collected during the $4 \mathrm{~d}$ ION station occupation in the Ionian Sea in the early morning of 29 May 2017 at 03:08 UTC. The second rain event (Rain FAST) occurred during the $5 \mathrm{~d}$ "Fast action" station occupation ("FAST") in the Algerian Basin during the night of 5 June 2017 at 00:36 UTC (Table 1). The two rain sample collections coincided with peaks in relative humidity and wind speed and minima in air temperature (not shown).

\subsubsection{Rain ION}

The ERA 5 data reanalysis shows two periods of precipitation in the vicinity of the $\mathrm{R} / \mathrm{V}$ position, i.e. in the morning and evening of 26 June (not shown) and in the night between 28 and 29 June 2017, in agreement with on-board visual observations. The rain event collected at ION was the product of a large cloud system, covering an area of about $90000 \mathrm{~km}^{2}$ around the R/V position and spreading over the Ionian and Aegean seas (Fig. 2). As no radar measurements were available for this area, the accumulated precipitation $(3.5 \pm 1.2 \mathrm{~mm})$ was estimated from ERA 5 data reanalysis on the grid point corresponding to the ION station $\left( \pm 0.25^{\circ}\right)$ around the $\mathrm{R} / \mathrm{V}$ position. The wash out of the atmospheric particles was revealed by the decrease in aerosol number concentrations monitored on board from about 1900 to 300 part. $\mathrm{cm}^{-3}$ (Supplement Fig. S1). Air mass backtrajectories showed that the scavenged air masses came from Greece both in the marine boundary layer and in the free troposphere (Fig. S1). The satellite observations also showed low aerosol optical thickness during this period (not shown), meaning that there were only low amounts of aerosols in the atmospheric column. No significant European pollution influence was monitored by on-board measurements during this event, with major gas mixing ratios and aerosol concentrations close to the average values of the cruise (Fig. S1), i.e. below the limit of detection for $\mathrm{NO}_{x}, 1.2 \mathrm{ppb}$ for $\mathrm{SO}_{2}$, $51 \mathrm{ppb}$ for $\mathrm{O}_{3}, 80 \mathrm{ppb}$ for $\mathrm{CO}$ and 3000 part. $\mathrm{cm}^{-3}$. On this basis, this wet event was representative of a Mediterranean background marine rain event.

\subsubsection{Rain FAST}

As detailed in Guieu et al. (2020a), the FAST position was decided on the basis of regional model forecast runs and satellite observations, for the purpose of catching a wet dust deposition event. Significant dust emissions were observed from NASCube (http://nascube.univ-lille1.fr/, last acess: 11 February 2022, Gonzales and Briottet, 2017) over North Africa from the night of 30-31 May 2017, then new dust emissions in the night from 3 to 4 June 2017 in Alge- 
Table 1. Information regarding the two rains datasets collected during the PEACETIME cruise.

\begin{tabular}{llll}
\hline Sample & Sampling time & $\begin{array}{l}\text { Station name (dates) and rain } \\
\text { location }\end{array}$ & Estimated total precipitation \\
\hline Rain ION & $\begin{array}{l}\text { 29 May 2017, } \\
\text { 03:08-04:00 (UTC) or } \\
\text { 05:08-06:00 (LT) }\end{array}$ & $\begin{array}{l}\text { ION }(25-29 \text { May) } \\
35.36^{\circ} \mathrm{N}, 19.92^{\circ} \mathrm{E}\end{array}$ & $3.5 \pm 1.2 \mathrm{~mm}$ \\
\hline Rain FAST & 5 June 2017, & & \\
& 00:36-01:04 (UTC) or & FAST (2-7 June $)$ & $6.0 \pm 1.5 \mathrm{~mm}$ \\
& $02: 36-03: 04$ (LT) & & \\
\hline
\end{tabular}
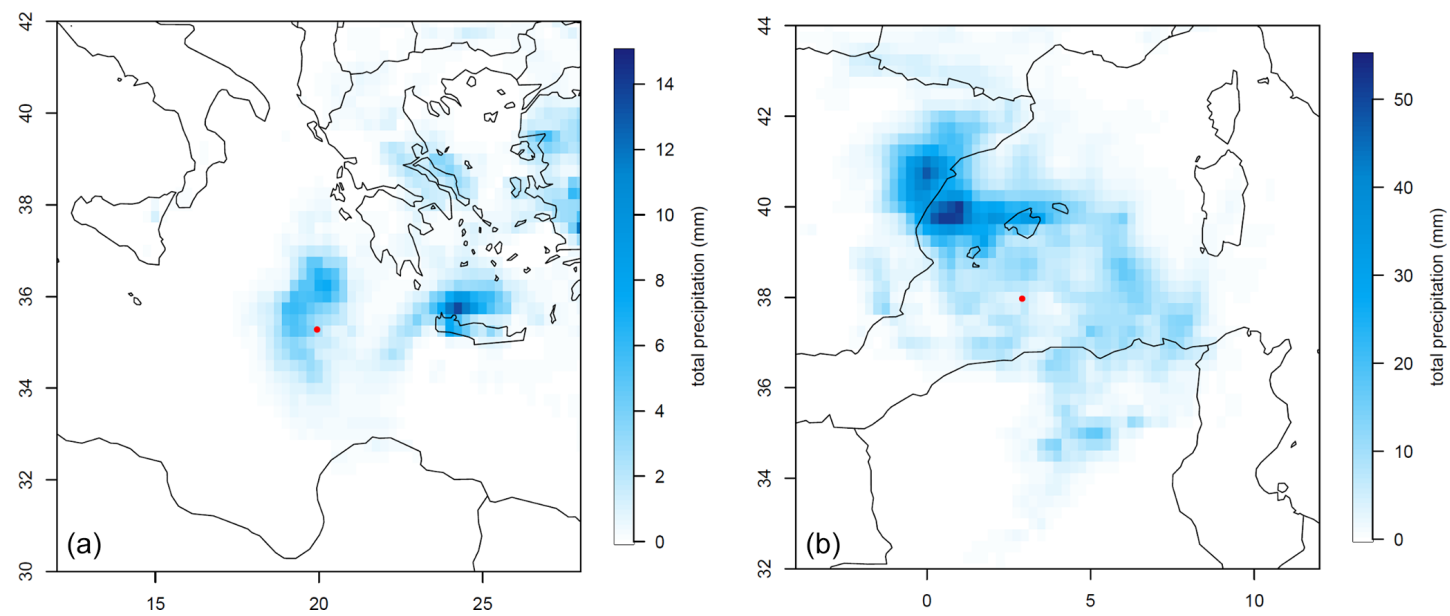

Figure 2. Total precipitation (mm) between 28 May at 20:00 UTC and 29 May 2017 at 10:00 UTC (Rain ION, a) and between the 4 June at 20:00 and 5 June 2017 at 09:00 UTC (Rain FAST, b) from ERA5 ECMWF reanalysis. The red circle indicates the R/V position. Note the different scales for total precipitation.

ria and southern Morocco associated with a northward atmospheric flux. On 30 May, the SEVIRI Aerosol Optical Depth (AOD) satellite product (https://www.icare.univ-lille. fr/data-access/browse-images/geostationary-satellites/ last acess: 11 February 2022, Thieuleux et al., 2005) confirmed the presence of atmospheric dust in a cloudy air mass over the western part of the Mediterranean, and from 2 June the export of a dust plume from North Africa south of the Balearic Islands with high AOD ( $>0.8)$ on the Alboran Sea was observed (Fig. S2). A dust plume with AOD $<0.5$ was transported to the northeast up to Sardinia on 4 June. Clear sky with low AOD remained west of $4^{\circ} \mathrm{E}$ on 5 June.

On-board lidar measurements (Fig. 3a, b, c) showed that the aerosol plume was present over the R/V position from 2 June 2017 at 21:00 UTC until the rain event and corresponded to a dust aerosol layer highlighted by the high depolarization. The dust plume was concentrated between 3 and $4 \mathrm{~km}$ at the beginning of the station occupation and expanded down to the marine boundary layer (about $500 \mathrm{~m}$ a.m.s.l.) by the end of the day on 3 June 2017. The mass-integrated concentrations of dust aerosols derived from the profiles of aerosol extinction ranged from a minimum of $0.18 \pm 0.005 \mathrm{~g} \mathrm{~m}^{-2}$ just before the rain to a maximum of
$0.24 \pm 0.009 \mathrm{~g} \mathrm{~m}^{-2}$, where standard deviations indicate the temporal variability $(1 \sigma)$.

Rain was observed by weather radar images in the area of the R/V from 3 June at 07:00 UTC. The rain recorded around FAST was associated with two periods of rain: from 07:00 to 14:00 UTC on 3 June and from 16:00 UTC on 4 June to 06:00 UTC on 5 June. For this latter case, a rain front $\left(100000 \mathrm{~km}^{2}\right)$, moving eastward from Spain and North Africa, reached the FAST station during the night between 4 and 5 June (Fig. 4). Wet deposition between 4 and 5 June in the FAST station area were confirmed by radar imagery, showing several other instances of rain around the R/V position before and after the rain sampling (Fig. 4). Continuous on-board lidar measurements confirmed the below-cloud deposition during the rain event of early 5 June (Fig. 3b). Rain FAST was a wet deposition event occurring at the end of an episode of transport of Saharan dust, whereas precipitation on the 3 June occurred during the maximum of the dust plume (Figs. 3b and S2). The surface concentrations of gas and particles, measured on board, suggest no clear dust or anthropogenic influence in the atmospheric boundary layer during this period of wet deposition, in agreement with back trajectories of low-altitude air masses (Fig. S2), 

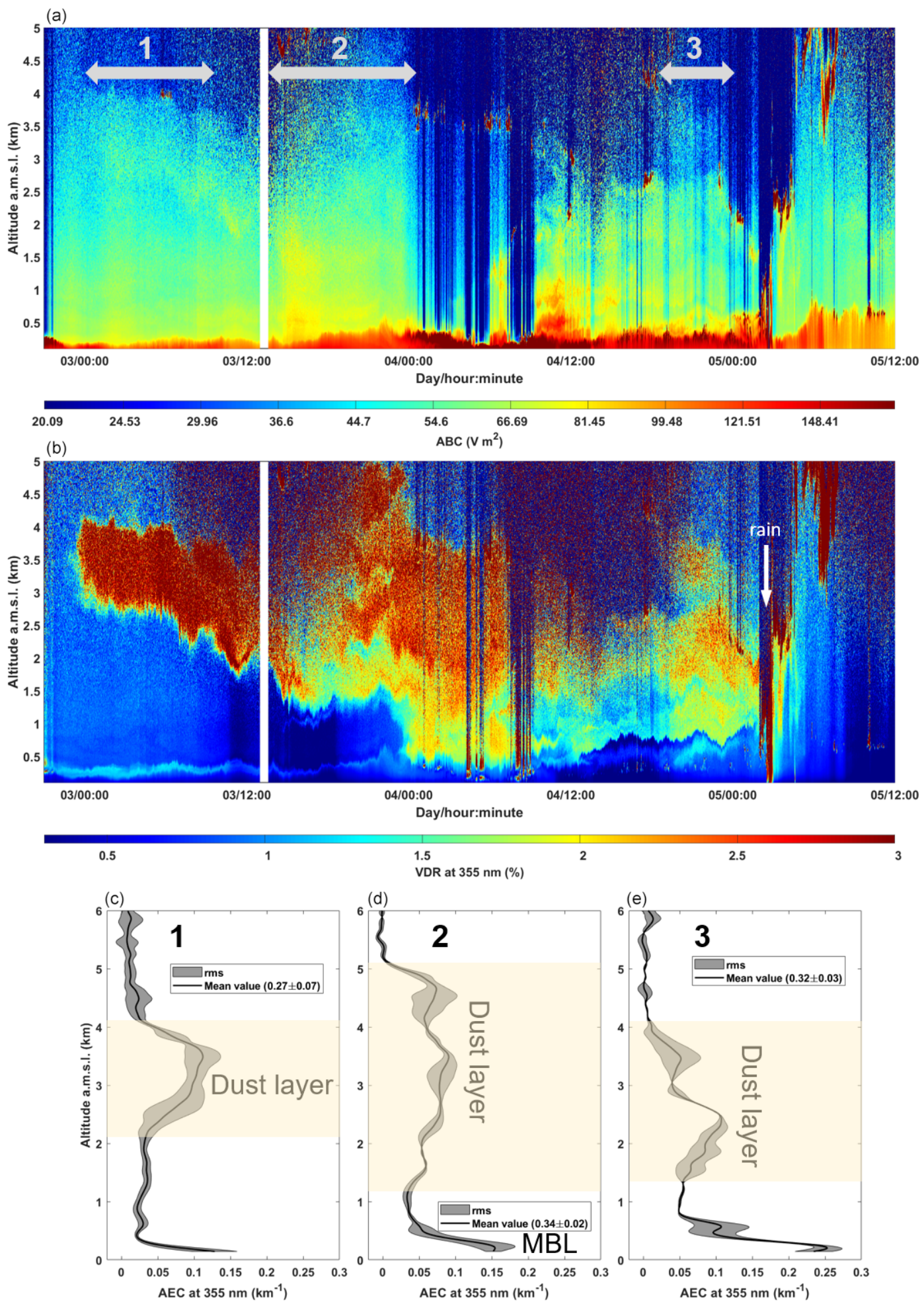

Figure 3. On-board lidar-derived (a) apparent backscatter coefficient (ABC); (b) temporal evolution of the lidar-derived volume depolarization ratio (VDR) (in LT), where the dust plume is highlighted for values higher than $\sim 1.7$ (yellow to red colours) and rain is shown by values higher than 3 (indicated by the white arrow); and (c) vertical profiles of the aerosol extinction coefficient in cloud-free conditions integrated over three periods denoted by 1, 2, and 3 in (a) along the dust plume event (c, d, e). The grey shade represents the root-mean-square (rms) variability along the time of the measurement. The dust layer is highlighted on the profiles. The mean aerosol optical thickness is given in the boxed legend with its temporal variability $(1 \sigma)$. The location of the marine boundary layer (MBL) is also shown. 
presuming no local mixing between dust and anthropogenic particles into rain samples. The total precipitation estimated from radar rainfall yields an accumulated precipitation of $6.0 \pm 1.5 \mathrm{~mm}( \pm 25 \mathrm{~km}$ around the $\mathrm{R} / \mathrm{V}$ position $)$, in agreement with ECMWF reanalysis ERA5 (Fig. 2) for the wet deposition on the night of 4-5 June $(5.7 \pm 1.4 \mathrm{~mm}$ in the grid point spanning the $\mathrm{R} / \mathrm{V}$ position, i.e. $\pm 0.25^{\circ}$ ).

\subsection{Chemical composition of rains}

Dissolved and total concentrations of nutrients and TMs in the rain samples are presented in Table 2. Among all measured dissolved concentrations, nitrate was the most abundant nutrient, followed by ammonium (Table 2). The nitrite concentration was below the limit of detection for the two rain samples. Regarding TMs in rain, Fe and $\mathrm{Zn}$ presented the highest concentrations both in the dissolved fraction and in total deposition with the same order of magnitude (10 to $\left.25 \mu \mathrm{g} \mathrm{L}^{-1}\right)$. Co, Cd and Mo had the lowest concentrations $\left(<0.1 \mu \mathrm{g} \mathrm{L}^{-1}\right.$ in both events, associated to the greatest uncertainties due to LoD), whereas the other TM concentrations ranged between 0.1 and $10 \mu \mathrm{g} \mathrm{L}^{-1}$ (Table 2). Concentrations of nutrients and the majority of TMs were higher in the dustrich rain, except dissolved $\mathrm{Pb}$ (similar concentrations in both rain samples) and $\mathrm{Cr}$ (3 times higher concentration in Rain ION relative to Rain FAST).

\subsection{Marine concentrations}

All the TMs had significantly higher concentrations in the ML compared to water below the ML and deeper (e.g. for Fe, see Bressac et al., 2021), in agreement with a stratified profile associated with atmospheric inputs. The pTM and dTM concentrations within the ML $(0-20 \mathrm{~m})$ are displayed in Fig. 5. Concentrations were of the same order of magnitude at ION and FAST. The TMs were mainly in dissolved forms in the ML (Kd from 0.006 to 0.5), except for Fe (Kd around 2) and one outlier value for $\mathrm{Zn}$ (1.3) (Fig. 5).

At both stations, the highest TM concentrations in the surface seawater were found for $\mathrm{dMo}(\sim 120 \mathrm{nM})$, these values are the first measurements published for the Med Sea and are in agreement with the high abundance of dMo in opensea water in other oceanic regions $(\sim 107 \mathrm{nM}$, Smedley and Kinniburgh, 2017). Fe is the most abundant in the particulate fraction in the ML $(\sim 4 \mathrm{nM})$. All the pTM and dTM concentrations measured during the cruise were within the range previously published for the Med Sea (Sherrell and Boyle, 1988; Saager et al., 1993; Morley et al., 1997; Yoon et al., 1999; Wuttig et al., 2013; Baconnais et al., 2019; Migon et al., 2020, GEOTRACES-IDP, 2021). However, dCo concentrations (from 10 to $20 \mathrm{pM}$ ) were among the lowest ones measured during stratification period in the western Med Sea ( 120 pM, Dulaquais et al., 2017). Zn presented the largest range of concentrations within the ML in both the dissolved and particulate fractions $(0.6$ to $19 \mathrm{nM}$ and 61 to $3300 \mathrm{pM}$ respectively) due to some high concentrations. However, the concentrations stayed in the typical range of values reported for the Med Sea (Béthoux et al., 1990; Yoon et al., 1999), even if we cannot exclude a possible contamination for these outlier concentrations.

\section{Discussion}

\subsection{Composition of rain collected over the remote Med Sea}

\subsubsection{Concentrations}

Regarding nutrients, nitrogen species concentrations in rain samples were in good agreement with those reported in Mediterranean rain samples, ranging from 1130 to $5100 \mu \mathrm{g} \mathrm{L}^{-1}$ for $\mathrm{NO}_{3}^{-}$and between 207 and $1200 \mu \mathrm{g} \mathrm{L}^{-1}$ for $\mathrm{NH}_{4}^{+}$(Loÿe-Pilot et al., 1990; Avila et al., 1997; Al Momani et al., 1998; Herut et al., 1999; Violaki et al., 2010; IzquietaRojano et al., 2016; Nehir and Koçak, 2018). The FAST rain concentrations were within the published range, whereas the ION rain was in the low range, confirming a background signature at this station. The rainwater samples presented a large dominance of $\mathrm{N}$ in comparison to $\mathrm{P}$, as observed from the $\mathrm{N} / \mathrm{P}$ ratio derived from DIN/DIP (Table 2), ranging from 208 at ION to 480 at FAST. Previous observations showed a predominance of $\mathrm{N}$ relative to $\mathrm{P}$ in the atmospheric bulk deposition over the Mediterranean coast, with an average ratio of about 100, the highest reaching 170 for DIN/DIP and 1200 for DIN/TDP (Markaki et al., 2010; Desboeufs et al., 2018). The highest ratio could be linked to a washout effect of gaseous $\mathrm{N}$ species $\left(\mathrm{NO}_{x}\right.$ and $\mathrm{NH}_{3}$ ) by rain (Ochoa-Hueso et al., 2011). At the two stations, observed $\mathrm{NO}_{x}$ concentrations were below the limit of detection in the boundary layer before wet deposition. The presence of nitrate and ammonium in the background aerosols has been observed during recent campaigns in the remote Mediterranean atmosphere (e.g. Mallet et al., 2019). To our knowledge, no data are available on both $\mathrm{P}$ and $\mathrm{N}$ concentrations in Mediterranean aerosols. The lowest concentrations of $\mathrm{P}$ relative to $\mathrm{N}$ in aerosol particles in the Mediterranean were observed during the cruise (DIN/TDP ranged from 13 to 790, Fu, 2018). The TDP concentrations were consistent with the average value of $8.4 \mu \mathrm{g} \mathrm{L}^{-1}$ measured in African dust rain samples collected in Spain over the 1996-2008 period (Izquierdo et al., 2012). Inorganic phosphorus predominated in the dust-rich rain, whereas organic $\mathrm{P}$ was dominant in the background rain as the contribution of DOP to the TDP was $60 \%$ and $44 \%$ in Rain ION and Rain FAST, respectively. The DOP/TDP ratio presents a very large range in Mediterranean rains, spanning from $6 \%$ in Spanish dusty rain samples (Izquierdo et al., 2012) to $75 \%-92 \%$ in rains from Crete (Violaki et al., 2018). A reason for this wide range could be that Mediterranean European aerosols, as opposed to Saharan dust parti- 


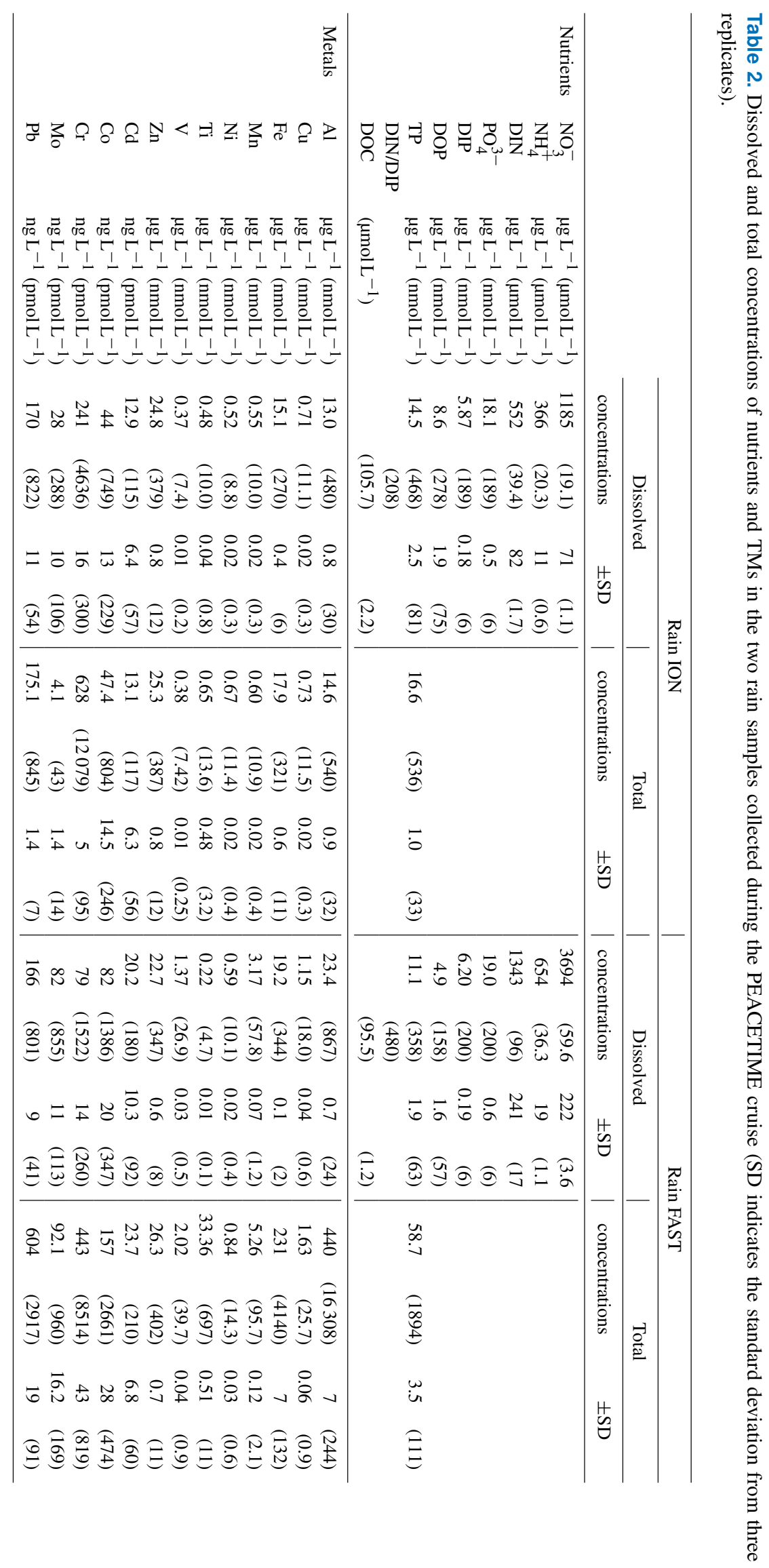




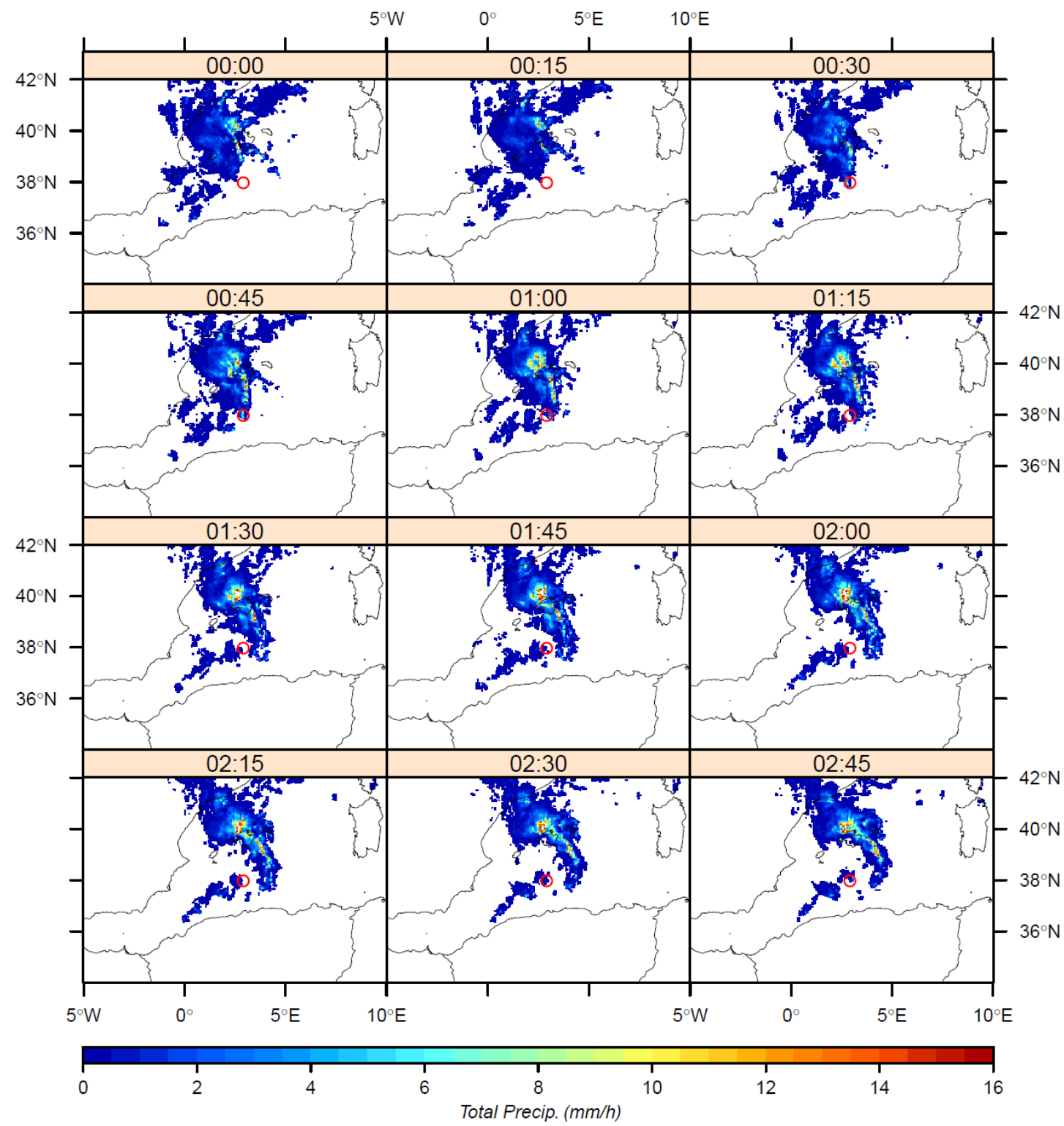

Figure 4. Rain rates $\left(\mathrm{mm} \mathrm{h}^{-1}\right)$ during the night between the 4 and 5 June when Rain FAST was collected on board. Issued from European rain radar composites (OPERA programme) of 5 June between 00:00 and 02:45 UTC.

cles, are dominated by organic phosphorus compounds associated with bacteria (Longo et al., 2014).

The dissolved and total TM concentrations in the PEACETIME rains were lower than those reported in coastal areas (for the eastern basin, see Özsoy and Örnektekin, 2009; AlMomani et al., 1998; Kanellopoulou et al., 2001, and for the western basin, see Guieu et al., 1997; Guerzoni et al., 1999; Chester et al., 1997; Losno, 1989; Frau et al., 1996), especially for the background Rain ION (Fig. 6). Most of the referenced works on coastal rainwater date from the late 1990s. There is a continuous decline of TM emissions since the 1990s due to regulatory efforts (Pacyna et al., 2007). The subsequent decrease in the anthropogenic $\mathrm{Cd}$ and $\mathrm{Pb}$ imprint on atmospheric inputs from European coasts to open sea is well documented (OSPAR, 2008; Travnikov et al., 2012; Geotraces IDP21). Since the phasing out of leaded automobile gasoline, the decrease in atmospheric $\mathrm{Pb}$ concentrations is also observed in the Mediterranean atmosphere (Migon et al., 2008). The low TM concentrations of ION and FAST rain samples, in particular $\mathrm{Cd}$ and $\mathrm{Pb}$, suggest a pronounced decrease in TM inputs in the open Mediterranean due to environmental mitigation on TM emissions. Moreover, the coastal deposition is generally not representative of opensea inputs, e.g. due to proximity of anthropogenic sources in coastal areas. Thus, the 1990s data should not be used as a current reference for open Mediterranean rain composition. 


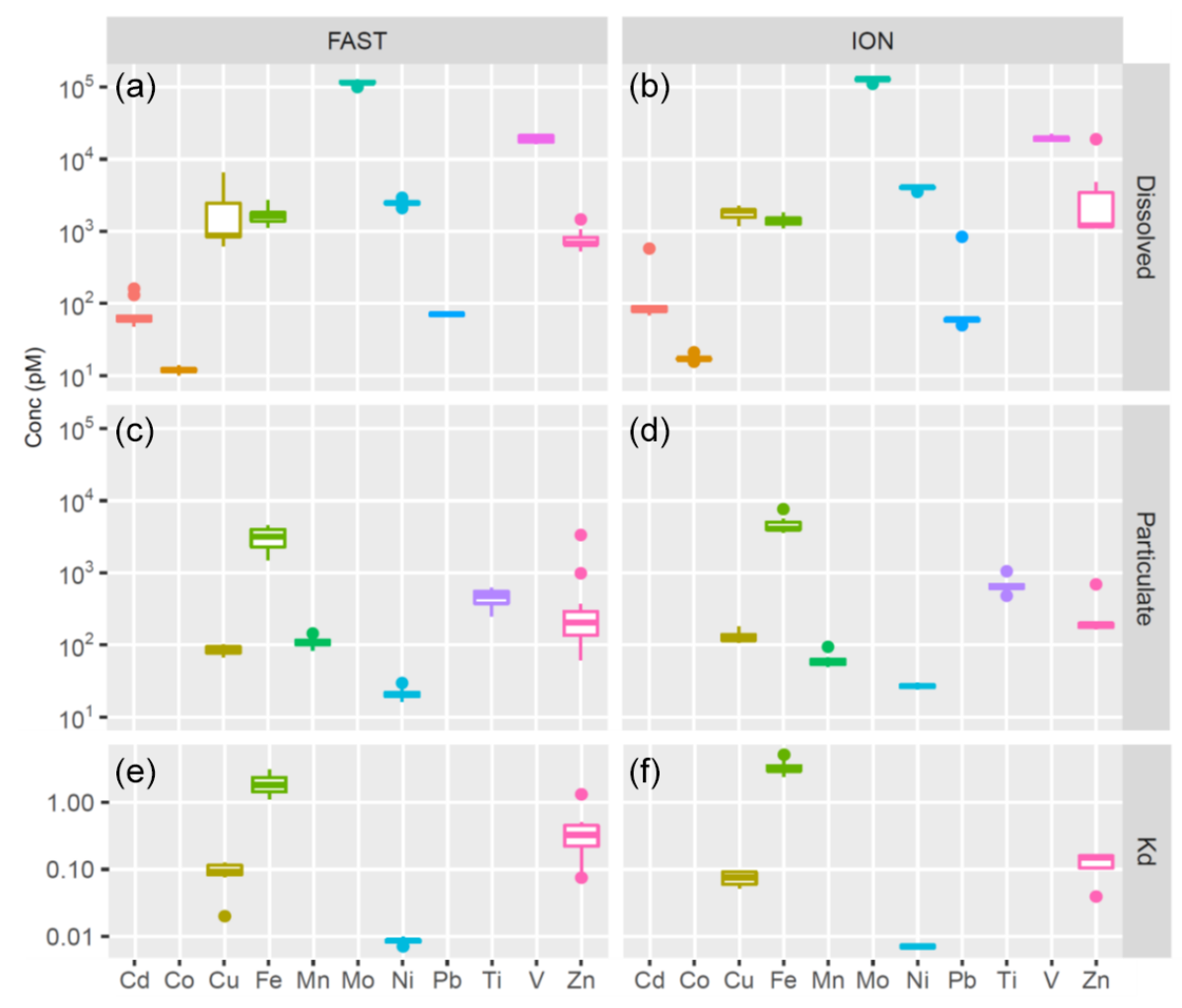

Figure 5. Box plots of dissolved (a, b) and particulate (c, d) marine concentrations (pM) and Kd values (e, f) for the different TMs within the ML at ION (b, d, f) and FAST (a, c, e). In the box plots, the box indicates the interquartile range, i.e. the 25 th and the 75 th percentile, and the line within the box marks the median. The whiskers indicate the quartiles \pm 1.5 times the interquartile range. Points above and below the whiskers indicate outliers outside the 10th and 90th percentile.

\subsubsection{Enrichment factor}

EF and solubility values of TMs and P observed during the two rain events contrasted greatly (Fig. 7). In Rain ION, almost all elements were significantly enriched relative to the upper continental crust (EF $>10$, and up to $\sim 10^{3}$ for $\mathrm{Cd}$ and $\mathrm{Zn}$, whereas in Rain FAST, only Zn (73), Cd (48), and Mo (15) were enriched. Only $\mathrm{Ti}, \mathrm{Fe}$, and $\mathrm{Mn}$ did not present a significant enrichment $(E F<10)$ in Rain ION, in agreement with previous studies in the Mediterranean environment showing that these metals are mainly associated with mineral dust in atmospheric deposition (e.g. Guieu et al., 2010; Desboeufs et al., 2018). However, for Fe and Mn an influence of non-crustal sources in Rain ION could be suspected through a clear increase in the EF values compared to FAST. Mo is the most abundant TM in seawater (Smedley and Kinniburgh, 2017), particularly in the Med Sea (see Sect. 3.3). Thus, in contrast to other TMs, the non-crustal part of Mo could be associated with sea salt aerosols rather than anthropogenic signal. The EF ratio relative to seawater $\left((\mathrm{Mo} / \mathrm{Na})_{\text {seawater }}=8.9 \times 10^{-7}\right.$ in mass ratio, Millero, 2013) was 7.4 for Rain ION and 4.6 for Rain FAST, confirming the marine origin of this element in both rain samples. The anthropogenic origin of TMs and $\mathrm{P}$ has been reported by several studies on atmospheric deposition monitoring in the western Mediterranean (e.g. Guieu et al., 2010; Sandroni and Migon, 2002; Desboeufs et al., 2018). For example, Desboeufs et al. (2018) showed that there is a large contribution of anthropogenic combustion sources to the $\mathrm{P}, \mathrm{Cr}, \mathrm{V}$ and $\mathrm{Zn}$ background deposition fluxes. Aerosol composition monitoring over the Mediterranean coastal area showed the role of landbased sources and ship traffic sources in TM contents (Bove et al., 2016; Becagli et al., 2017). As all the deposition measurement sites were located in coastal areas, it was difficult to exclude the influence of these local sources for explaining the observed anthropogenic contribution. Here, EF values showed a clear anthropogenic signature for $\mathrm{P}$ and all TMs except Ti, Fe, Mn and Mo in the offshore Rain ION sample. In particular, the EF of $\mathrm{Zn}$ in Rain ION was on average 5 times higher than the EF found in the rain samples previously studied from coastal sites in the Mediterranean region (Özsoy and Örnektekin, 2009; Al-Momani et al., 1998; Losno, 1989). Nevertheless, extremely high enrichments of $\mathrm{Zn}$ in rainwater have been reported from island sites in the Med Sea; for example, Frau et al. (1996) reported geometric mean EF of $\sim 6500$ in both dust-rich and dust-poor rains from two sites in southern Sardinia, and Fu et al. (2017) reported EF $>1000$ for $\mathrm{Zn}$ in atmospheric insoluble bulk (wet+dry) deposition 


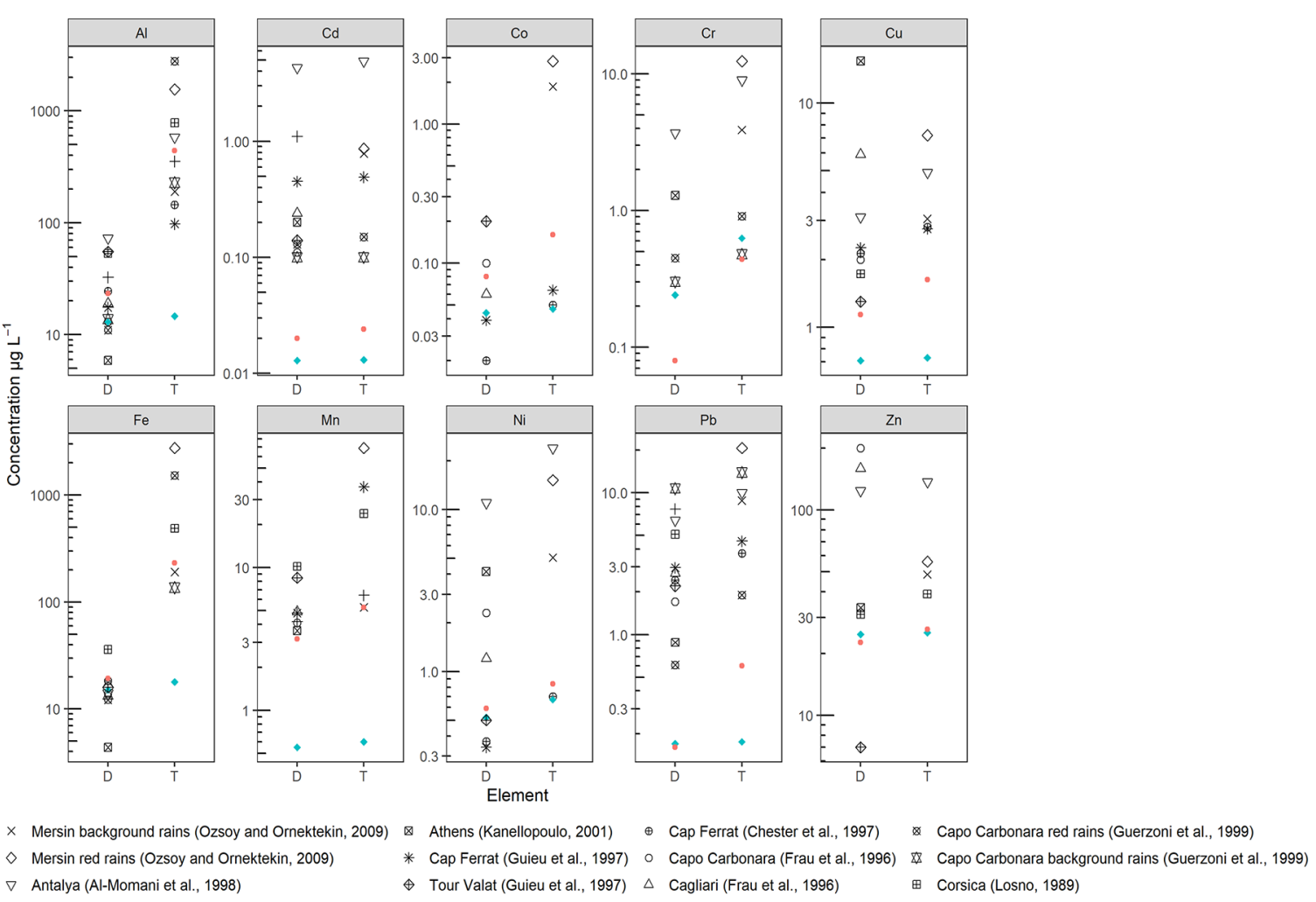

- Rain 1 (this study)

Rain 2 (this study)

$\boxplus$ Corsica (Losno, 1989)

Figure 6. Comparison of dissolved (D) and total (T) TM concentrations to previous studies in the eastern and western Med Sea.

on Lampedusa Island. As previously discussed (Sect. 3.1.1.), Rain ION was representative of a Mediterranean background marine rain event. The $\mathrm{Zn} \mathrm{EF}$ at ION was the same order of magnitude as at these island sites, which suggests a high anthropogenic background signal of $\mathrm{Zn}$ even in the open Med Sea. More generally, the high EFs in Rain ION mean that the chemical composition of background aerosol particles is likely continuously impacted by anthropogenic sources even over the remote Med Sea.

The EF values of TMs for Rain FAST were significantly lower than for Rain ION (Fig. 7) but were similar to Saharan rains (Guerzoni et al., 1999; Özsoy and Örnektekin, 2009), confirming the dust signature for this rain. The comparison between dust-rich and background rains generally reveals a net difference of concentrations (at least higher by a factor of 3 in dust-rich rains), particularly for $\mathrm{Al}, \mathrm{Fe}, \mathrm{Mn}$ and $\mathrm{Cr}$ (Guerzoni et al., 1999; Özsoy and Örnektekin, 2009). Here, an increase in concentrations between Rain ION and Rain FAST was observed for the majority of TMs: $\mathrm{Al}(\times 28), \mathrm{Ti}$ (×50), Mo (×23), Fe (×13), Mn (×9), V (×5), Pb (×3.5), $\mathrm{Co}(\times 3)$, and $\mathrm{Cu}(\times 2)$ and also for $\mathrm{P}(\times 4)$ (Table 2$)$. The combination of higher concentrations and EF values $<10$ found in Rain FAST show that the dust contribution was important on deposition fluxes of many TMs and P during this event. However, the high Al concentrations in Rain FAST drives EF values down mathematically, masking other potential source signatures.

\subsubsection{Solubility}

The solubility values were also higher in Rain ION than in the dusty Rain FAST, except for Mo, for which the difference between both rain samples was not significant (Fig. 7). For Rain ION, TMs and P presented solubility higher than $78 \%$, except for $\mathrm{Cr}$ which had a solubility of $38 \%$. In Rain FAST, solubility values $<10 \%$ were observed for $\mathrm{Al}$ and $\mathrm{Fe}$, more than 10 times lower than in Rain ION. For the other TMs, the highest difference in solubility was observed for $\mathrm{Pb}$, whose solubility decreased from $97 \%$ in Rain ION to $27 \%$ in Rain FAST. In a review on TM solubility in Mediterranean rainwater collected in coastal areas, Desboeufs (2022) emphasize the large range of solubility for all the TMs: $\mathrm{Fe}$ $(0.8 \%-41 \%), \mathrm{Cr}(6 \%-80 \%), \mathrm{Pb}(5 \%-90 \%)$, Ni $(22 \%-$ $93 \%), \mathrm{Mn}(16 \%-95 \%), \mathrm{Cu}(22 \%-96 \%), \mathrm{Zn}(14 \%-99 \%)$, $\mathrm{V}(35 \%-99 \%)$ and $\mathrm{Cd}(72 \%-99 \%)$. The solubility ranges found in this study were generally consistent with those reviewed by Desboeufs (2022). Moreover, the Mn solubility values in FAST $(60 \%)$ and ION $(92 \%)$ rains are close to those reported by Dulac (1986) from a dust-rich (57\%) and anthropogenic $(83 \%)$ rain collected at sea in the Ligurian Sea and west of Sardinia in April 1981. Only Fe solubility ( $84 \%$ ) found in Rain ION was higher than the average values previously reported. In the Rain FAST, Fe solubility was $8 \%$, this is 10 times lower than the average Fe solubility in 10 dust-rich rains collected on the southeastern coast of Sar- 

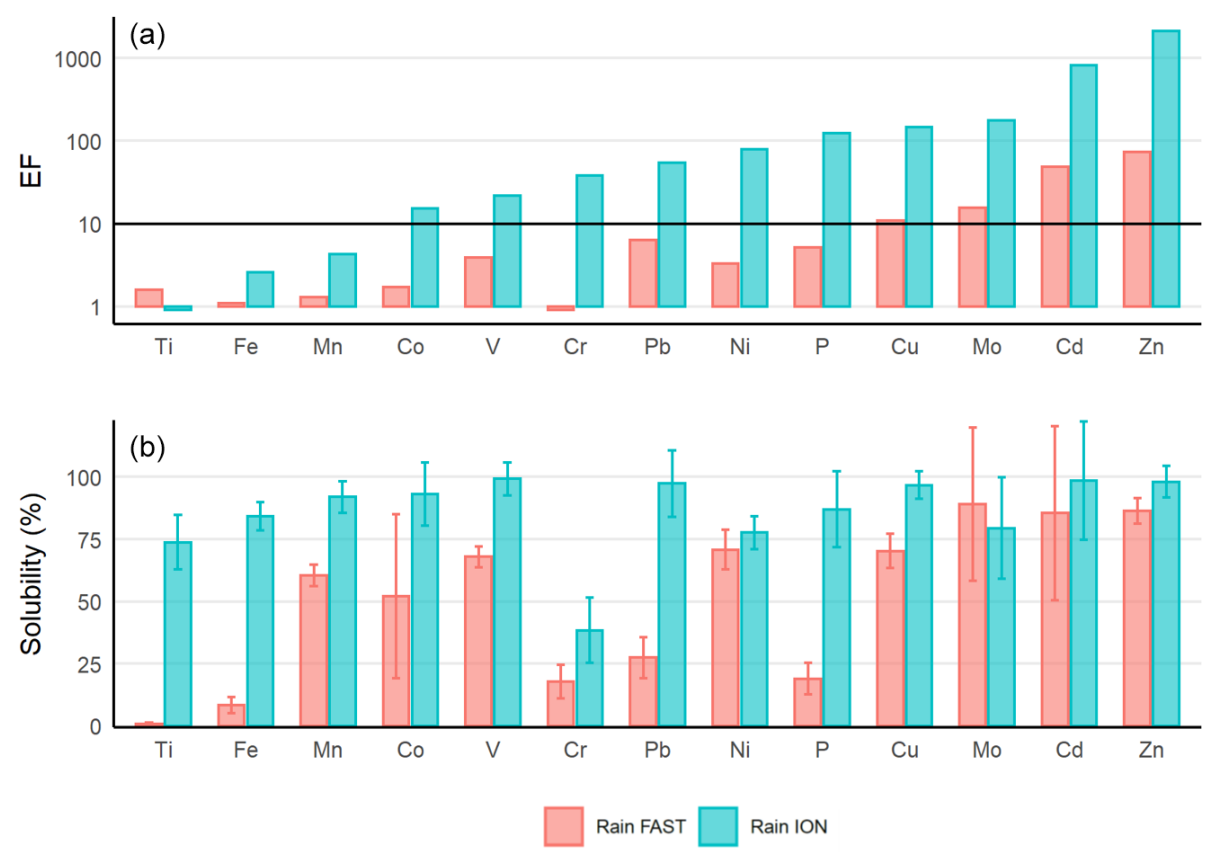

Figure 7. Enrichment factor $(\mathrm{EF}, \mathbf{a})$ and solubility $(\%, \mathbf{b})$ of phosphorus $(\mathrm{P})$ and TMs ordered by increasing EF in the two rainwater samples.

dinia by Guerzoni et al. (1999) but consistent with Saharan dust deposition collected in the Atlantic Ocean (Sedwick et al., 2007; Baker et al., 2013). It is known that anthropogenic $\mathrm{Fe}$ is more soluble than Fe-bearing dust (Desboeufs et al., 2005; Jickells et al., 2016). Regarding the evolution of TM emissions (see Sect. 4.1.1), we suspect that this difference could be due to a higher contribution of anthropogenic signal for Fe in dust-rich rains in 1990s in Sardinia than in the recent rain samples.

Few studies have compared TM solubility between dustrich and anthropogenic rains in the Mediterranean. An increase in solubility values from dust-rich to background rains was observed for $\mathrm{Mn}$ in offshore rains, as mentioned above (Dulac, 1986), and for $\mathrm{Al}, \mathrm{Cr}, \mathrm{Fe}$ and $\mathrm{Pb}$ (with only a slight increase for Cd) in Sardinia (Guerzoni et al., 1999). The decrease in solubility from background to dust-rich rains was observed for P in Spain by Izquierdo et al. (2012), with values of solubility decreasing from $25 \%$ to $7 \%$. Here, our results for the two rain samples confirm the lowest solubility of TMs in dust-rich rains (except for Mo). Aerosol-leaching experiments showed that metal dissolution from aerosol particles can be also influenced by a number of parameters, such as $\mathrm{pH}$, presence of dissolved organic complexing ligands, incloud processing, and particle origin and load (Desboeufs et al., 1999; Bonnet and Guieu, 2004; Desboeufs et al., 2005; Paris and Desboeufs, 2013; Heimburger et al., 2013; Jickells et al., 2016). However, it is known that metals that are mainly associated with crustal aluminosilicate mineral lattices such as Fe and Ti have very low solubility values, due to the difficulties with breaking bonds in the lattices (Journet et al., 2008; Jickell et al., 2016). Regarding metal partition- ing in rainwater, the role of $\mathrm{pH}$ and of the particulate mineral dust loading, reflecting the dust versus anthropogenic signature, were identified as the main controls of TM solubility in the Mediterranean rainwater (Özsoy and Örnektekin, 2009; Theodosi et al., 2010). From our two rain samples, it is difficult to propose a control explaining the difference in solubility values. However, the $\mathrm{pH}$ values were very close in the two samples (Table 2), excluding a pH effect on solubility values. The much lower solubility of TMs in Rain FAST is consistent with the EFs indicating a crustal origin of TMs in Rain FAST (Fig. 7). As discussed before, background atmosphere in the Med Sea seems to be continuously influenced by anthropogenic particles. Even in dusty Rain FAST, it is highly probable that a part of metals presented an anthropogenic imprint is not visible on EF values but has solubility similar to Rain ION. Thus, the decrease in solubility between the two rain samples could either be due to the lower solubility of TMs in mineral dust (as suggested by aerosol leaching experiments) or the presence of mineral dust, which by increasing the TM total concentrations overwhelms the anthropogenic background signal, or both. The case of Mo is unique, since its solubility was comparable in Rain ION and Rain FAST. As discussed with EF values, Mo was associated with sea salt aerosols in both rain samples, explaining the similarity of solubility. 


\subsection{Atmospheric wet deposition as a source of TMs to the surface seawater}

\subsubsection{Atmospheric fluxes}

As mentioned before, the two collected rains were part of large rain systems associated with patchy rainfall that lasted several hours or days (see Sect. 3.1). This spatio-temporal variability led to heterogeneity in both rainwater concentrations and accumulated precipitation across the studied region. Such spatial variability has been observed in the Atlantic Ocean (Chance et al., 2015; Powell et al., 2015). Moreover, even weak lateral advection can transfer surface water impacted by intense precipitation in the vicinity of the vessel. On this basis, the spatial extrapolation of wet deposition fluxes seems subject to large uncertainties (almost 100\% relative standard deviation, RSD) when the rain samples are not collected across the rain area (Chance et al., 2015). To best counteract this effect, spatial variability was taken into account to quantify the total precipitation, i.e. $3.5 \pm 1.2 \mathrm{~mm}$ for Rain ION and $6.0 \pm 1.5 \mathrm{~mm}$ for Rain FAST (see Sect. 3.1), in order to quantify the wet deposition fluxes ( $\sim 25 \%$ RSD for total precipitation and $1 \%$ to $74 \%$ RSD for concentration).

From the total (dissolved + particulate) $\mathrm{Al}$ concentration measured in the Rain FAST sample, we estimated the wet mineral dust deposition flux at $65 \pm 18 \mathrm{mg} \mathrm{m}^{-2}$, assuming $7.1 \% \mathrm{Al}$ in dust (Guieu et al., 2002). The vertical distribution of dust particles (Fig. 3b) and the absence of high Al concentrations close to the sea surface (Fu, 2018) indicate that dust dry deposition can be neglected. Based on the increase in total $\mathrm{Al}$ in the upper $20 \mathrm{~m}$ of the column water following the deposition events and using $7.1 \%$ for $\mathrm{Al}$ in dust, Bressac et al. (2021) derived an average dust deposition flux of $\sim 55 \mathrm{mg} \mathrm{m}^{-2}$ at FAST, which is comparable to our estimate. Although low compared to deposition fluxes reported in the western Mediterranean (Bergametti et al., 1989; Loÿe-Pilot and Martin, 1996; Ternon et al., 2010), our flux estimates are of the same order of magnitude as the most intense weekly dust deposition fluxes calculated more recently in Corsica between 2011 and 2013 (14\% of fluxes $>50 \mathrm{mg} \mathrm{m}^{-2}$ ) and are comparable to the mean weekly flux $\left(93 \mathrm{mg} \mathrm{m}^{-2}\right)$ reported for Mallorca during the same period (Vincent et al., 2016). The columnar aerosol concentration during the dust event at FAST is estimated to be between 0.18 and $0.24 \mathrm{~g} \mathrm{~m}^{-2}$ (see Sect. 3.1), and thus the expected maximum values of atmospheric dust flux could be in this range. The comparison with the estimated flux indicates that the atmospheric column was probably not totally washed out by the short rain event. Indeed, Fig. 3b shows that a significant depolarization was observed immediately after the rain ended on the R/V, before atmospheric advection could have brought dusty air possibly not affected by rain. Satellite products (Fig. S2) confirm that the dusty air mass was transported further to the northeast from the station on 5 June, where it was replaced by clear air.
The atmospheric dissolved and particulate wet deposition fluxes of TMs, derived from the chemical composition and total precipitation of rain samples, are presented in Fig. 8. $\mathrm{Co}$, Mo and $\mathrm{Cd}$ presented the lowest fluxes in the two rainfalls. $\mathrm{Zn}$ and $\mathrm{Fe}$ fluxes were of the same order of magnitude and were the highest dissolved fluxes compared to the other TMs in the two rains. The $\mathrm{Kd}$ values $(0.1<\mathrm{Kd}<1)$, consistent with solubility values higher than $50 \%$ (Fig. 7), show that whatever the rain sample, the atmospheric TM inputs were mainly dissolved, except for those of $\mathrm{Fe}, \mathrm{Pb}$ and $\mathrm{Ti}$ in Rain FAST and Cr in both rains (Fig. 8). The comparison shows that almost all of the dTM fluxes were higher in the dusty rain, except for $\mathrm{Cr}$ and $\mathrm{Ti}$ due to their low solubility in Rain FAST. Our results suggest that dust deposition resulted in higher atmospheric inputs of TMs than from low perturbed anthropogenic background rain, even here in the case of the reported moderate deposition input flux. There is more than an order of magnitude difference in deposition fluxes between the two rain events, and this is most notably the case for particulate $\mathrm{Fe}, \mathrm{Mn}, \mathrm{Pb}$ and $\mathrm{Ti}$, which are typically poorly soluble when coming from desert dust sources. Dissolved $\mathrm{Cd}, \mathrm{Co}, \mathrm{Cu}, \mathrm{Mn}$ and $\mathrm{V}$ fluxes present the highest increases between background Rain ION and dusty Rain FAST. However, these former elements (except Mn) are usually considered to have come from anthropogenic sources. The orders of magnitude found in this study could be used as a benchmark to estimate atmospheric inputs of TMs from wet deposition to the western Med Sea. However, we must keep in mind that annual and long-term deposition fluxes of desert dust-related elements, such as Fe, Mn and Ti (e.g. Ternon et al., 2010), as well as nitrogen species (e.g. Richon et al., 2018b), are dominated by a few atypical intense deposition events in the Med Sea, as is the case in many other oceanic regions (Duce et al., 1991).

\subsubsection{Comparison between TM wet deposition inputs and marine stocks at FAST}

As described in Guieu et al. (2020a), marine dynamic conditions at FAST were favourable to observe any change in the water masses strictly attributed to external inputs coming from the atmosphere on a short timescale. The impact of the dust wet deposition on nutrient stocks in Mediterranean surface waters is discussed in detail in Van Wanbeke et al. (2021b) and Pulido-Villena et al. (2021). To briefly summarize, both nitrate and DIP increased in the ML following the rain. Although the closure of the $\mathrm{N}$ and $\mathrm{P}$ budgets had to necessarily take into account post-deposition processes such as new nutrient transfer through the microbial food web (uptake, remineralization, and adsorption or desorption processes on sinking particles), it was shown that wet deposition was a significant source of nutrients for the ML during the cruise. For example, atmospheric supply of phosphate could contribute to $90 \%$ of new production at FAST (Pulido-Villena et al., 2021). Bressac et al. (2021) studied 


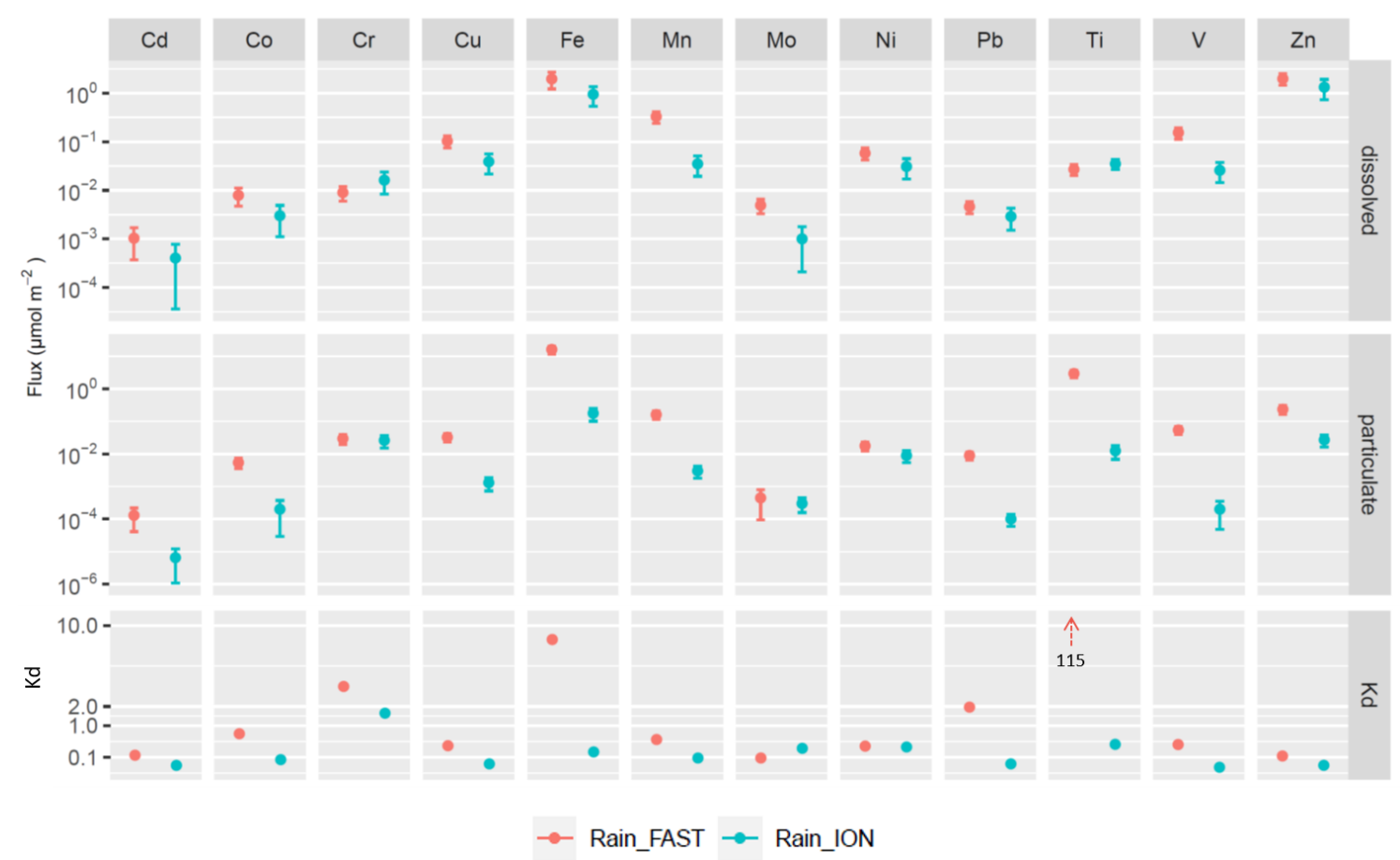

Figure 8. Dissolved (upper row) and particulate (middle row) wet deposition fluxes $\left(\mu \mathrm{mol} \mathrm{m}{ }^{-2}\right.$ ) and Kd (lower row) for the different TMs estimated from the two rains sampled on board, taking into consideration the standard deviation of the TM concentrations and the spatial variability of total precipitation over the area of sampling (Rain ION is shown in blue, and Rain FAST is shown in red). Note the different scales of the $y$ axes and that the Kd value for Ti (115) in Rain FAST is out of scale.

the response to $\mathrm{Al}$ and $\mathrm{Fe}$ cycles to dust deposition during the cruise. They showed that total $\mathrm{Fe}$ and $\mathrm{Al}$ stocks were increased by dust wet deposition and that the dissolved $\mathrm{Fe}$ atmospheric inputs were transient in the ML and were accumulated in the subsurface waters $(100-1000 \mathrm{~m})$. The low depth resolution of marine TM concentration samplings prevents the creation of TM inventories of the water column. We focus here on the role of dust wet deposition events as a source of TMs to the surface mixed layer, but we do not focus on Mo due its marine origin in the rain samples. The deltas of TM stocks before and after Rain FAST compared to the atmospheric fluxes are presented in Fig. 9.

After Rain FAST, ML stocks increased for $\mathrm{pFe}(+61 \%)$, pMn $(+15 \%), \mathrm{pTi}(+23 \%)$ and $\mathrm{pZn}(+9 \%)$ and for $\mathrm{dCo}$ $(+6 \%)$ and $\mathrm{dFe}(+46 \%)$ (Fig. 9). The behaviour of $\mathrm{pFe}$, $\mathrm{pMn}, \mathrm{pTi}$ and $\mathrm{pZn}$ is consistent with observations of $\mathrm{pAl}$ stock, which increased by $78 \%$ after rain (Bressac et al., 2021). The atmospheric particulate inputs were higher for the marine particulate deltas for all the TMs (Fig. 9), supporting the idea that the marine stock increases resulted from atmospheric inputs. The pTM inputs by rain were also observed from the Kd increase in the ML for Fe (1.7 to 1.9) and $\mathrm{Zn}$ ( 0.33 to 0.57$)$, in agreement with the highest $\mathrm{Kd}$ values in rain fluxes (Fig. 8) relative to marine ratio (Fig. 5). The increase in $\mathrm{Kd}$ was even observed for $\mathrm{Cu}(0.044$ to 0.091$)$ and $\mathrm{Ni}(0.0081$ to 0.0086$)$, for which no change in stock could be evidenced. It is probable that the rain inputs for these TMs are masked in the uncertainties of stock estimations. As dissolved concentrations of $\mathrm{Mn}$ and $\mathrm{Ti}$ were not measured in the ML, it is not possible to estimate the Kd values. However, the particulate $\mathrm{Mn} / \mathrm{Al}$ ratio fell from 0.27 before the rain to 0.008 after the rain, in accordance with the rain ratio (0.002), confirming the impact of rain inputs on marine particulate stocks of $\mathrm{Mn}$ and $\mathrm{Al}$. For Ti, the particulate Ti/Al ratios were very close in the ML (0.048) and in the rain (0.045), making it impossible to observe a rain effect. Here, the observed deltas were less than the rain inputs. However, the marine sampling was performed $4 \mathrm{~h}$ after the rain. Bressac et al. (2021) showed a decrease of $40 \%$ in the pAl signal over $24 \mathrm{~h}$, which could be explained by either a rapid settling of dust in the ML or lateral advection. The dynamic of $\mathrm{pFe}$, pMn and pTi stocks, with a decrease over time after rain (not shown), is consistent with dust removal in the ML. The $\mathrm{pCu}$ and $\mathrm{pNi}$ inputs represented $4 \%$ and $10 \%$ of particulate marine stocks. The dust removal could overwhelm the signal of enrichment of these metals. However, we cannot exclude the idea that the $\mathrm{pCu}$ and $\mathrm{pNi}$ inputs were masked by the uncertainties in the stock calculations.

For dissolved stocks, no enrichment was observed for $\mathrm{Cd}$, $\mathrm{Cu}, \mathrm{Ni}, \mathrm{Pb}$ and $\mathrm{Zn}$. This is not surprising for $\mathrm{Cd}, \mathrm{Cu}, \mathrm{Ni}$, $\mathrm{Pb}$ and $\mathrm{V}$ since atmospheric dissolved inputs represent less than $1 \%$ of marine stocks. As expected from the comparison 

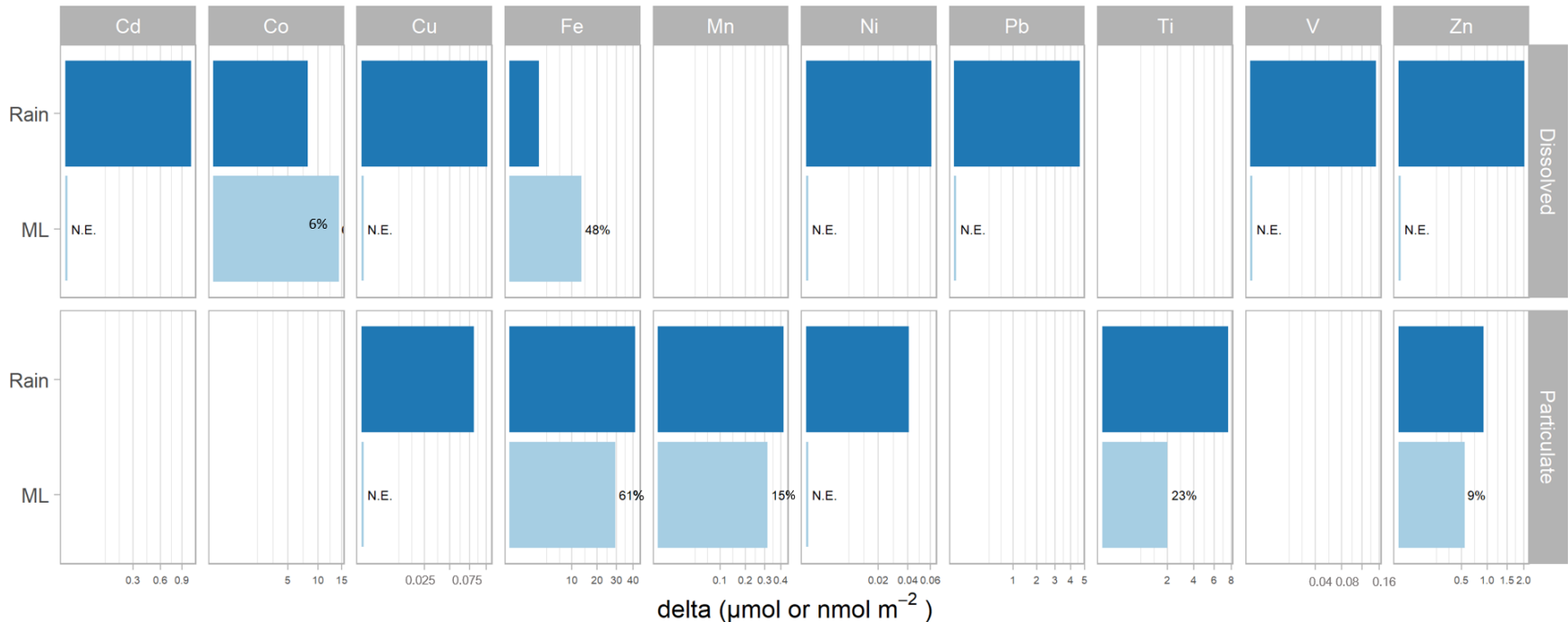

Figure 9. Comparison between TM wet deposition fluxes (dark blue) and TM marine stock deltas (before and after the rain) in the ML (light blue) at FAST. Dissolved stocks are given in the upper panels, and particulate stocks are given in the lower panels. Marine stock increases are expressed as absolute values $\left(\mathrm{Cd}, \mathrm{Co}\right.$ and $\mathrm{Pb}$ stocks and fluxes are given in $\mathrm{nmol} \mathrm{m}^{-2}$, and the other $\mathrm{TMs}$ are given in $\mu \mathrm{molm} \mathrm{m}^{-2}$ ) and in relative values (\%). N.E. stands for not enhanced (increase $<5 \%$ ).

between inputs and stocks before rain, the marine $\mathrm{dCo}$ and dFe stocks were increased after dust deposition. However, the marine deltas within the ML for Co and Fe were 2 and 7 times higher, respectively, than what could be provided from the atmospheric dissolved inputs. A lateral transport and cumulative effect of previous and surrounding wet deposition events (from 3 June) could explain this positive mismatch. Several removal processes occurring in the ocean, such as biological uptake (Morel et al., 2003; Noble et al., 2008), passive scavenging by adsorption onto particles (Wuttig et al., 2013; Bressac and Guieu, 2013; Mackey et al., 2015; Migon et al., 2020) or chemical processes such as precipitation (Wagener et al., 2010; Ye et al., 2011) are known to decrease dissolved TM concentrations in the first 24 to $48 \mathrm{~h}$ after atmospheric deposition. During the cruise, Bressac et al. (2021) showed that dust deposition represented a significant input of dissolved $\mathrm{Fe}$ in the ML only on a timescale of hours, which is due to scavenging or precipitation processes. It is highly probable that these removal processes limited the cumulative effect of dTM inputs. A post-deposition dissolution of $\mathrm{Fe}$ and $\mathrm{Mn}$ in seawater was reported during dust-seeding experiments simulating wet dust deposition in mesocosms over several hours or days (Wagener et al., 2008; Wuttig et al., 2013; Desboeufs et al., 2014). Mackey et al. (2015) show that in cases of dry deposition, aerosol $\mathrm{Co}$ and $\mathrm{Fe}$ dissolution in seawater can be gradual and can continue up to $7 \mathrm{~d}$ after contact with seawater. Considering the excess of TMs in marine stocks relative to rain inputs, our observations are consistent with the dissolution of $\mathrm{Co}$ and $\mathrm{Fe}$ in surface seawater following the first hours after wet dust deposition. Tovar-Sánchez et al. (2020) proposed that UV irradiation and the enrichment in organic matter in the SML could enhance the dissolution processes and the diffusive transfer between SML and surface seawater. They estimated that the residence times ranged from $23 \mathrm{~min}$ for $\mathrm{pFe}$ to $3.5 \mathrm{~h}$ for $\mathrm{pCo}$ in the SML after Rain FAST. From these timescales, the contribution of dissolution followed by diffusive processing of $\mathrm{dCo}$ and $\mathrm{dFe}$ from the SML to ML in post-depositional dissolution processes could be considered. The increase in dissolved stocks also suggests that in the first hours after rain the dissolution processes were predominant over removal processes in the behaviour of $\mathrm{dCo}$ and $\mathrm{dFe}$. With Co and Fe being known to limit phytoplankton biomass, a biological uptake could be predominant if marine biota were limited for these elements. This was probably not the case here. The behaviour of $\mathrm{Zn}$ is more complicated to interpret since no enrichment was observed, whereas the atmospheric $\mathrm{dZn}$ inputs represented around $12 \%$ of marine stocks. This unexpected behaviour could be explained by the predominant role of removal processes relative to postdepositional dissolution. The high solubility of $\mathrm{Zn}$ in Rain FAST $(\sim 86 \%)$ relative to solubility values of $\mathrm{Fe}(8 \%)$ or $\mathrm{Co}$ $(52 \%)$ suggests that all the soluble $\mathrm{Zn}$ was already dissolved in the rain inputs before contact seawater.

Finally, our results show that the studied atmospheric dust event was a net source of particulate TMs and dissolved $\mathrm{Fe}$ and $\mathrm{Co}$ for the ML at FAST. Due to various marine post-deposition processes, it is more complicated to observe the effect of wet deposition on dissolved stocks. Even if the wet deposition already delivered TMs in soluble form (Fig. 8), our results showed that the wet deposition constitutes a source of only some of dissolved TMs for surface waters in the Med Sea. The post-deposition dissolution of particulate rain inputs could represent an additional pathway of dissolved TM supply for the surface ocean, notably for 
low-solubility TMs in wet deposition. Thus, using only the dissolved atmospheric fluxes could underestimate dissolved atmospheric inputs of TMs to ML inventories. On a timescale of hours, the Fe inventory was the most impacted by the dusty rain input, both in dissolved and particulate phases, confirming that the dust-rich rains are an external source of Fe to the surface Med Sea (Bonnet and Guieu, 2006; Bressac et al., 2021).

\subsubsection{Comparison between TM wet atmospheric inputs and marine stocks in the western and central Med Sea}

As discussed from dissolved TM stocks at FAST, high surface marine TM stocks masked any additional input for several TMs. However, the collected rains (FAST and ION) originated from large rain systems covering more than $50000 \mathrm{~km}^{2}$ around the sampling zone and were typical of Mediterranean wet deposition. The wet deposition could have occurred in any of the explored areas during the cruise. Here we further study the role of wet deposition by comparing atmospheric dissolved fluxes to marine dissolved stocks from TM profiles in the ML at all 13 marine stations, i.e. 22 ML samplings, throughout the whole cruise (Fig. 10). Exceptional intense dust deposition events have been recorded in the Mediterranean, reaching $20 \mathrm{~g} \mathrm{~m}^{-2}$ (Bonnet and Guieu, 2006). Sporadic and intense wet dust deposition higher than $1 \mathrm{~g} \mathrm{~m}^{-2}$ is observed in the spring in the western Mediterranean Basin (e.g. Vincent et al., 2016). At the beginning of the cruise, an intense wet dust deposition event (not collected) occurred over the southern Sardinia and over the Tyrrhenian Sea, with fluxes reaching about $9 \mathrm{~g} \mathrm{~m}^{-2}$ (Bressac et al., 2021). In order to take into account the effect of such an intense event, we also estimated the atmospheric fluxes of dissolved TMs based on a $9 \mathrm{~g} \mathrm{~m}^{-2}$ wet dust deposition event using solubility values estimated from Rain FAST (Fig. 10). $\mathrm{Fe}, \mathrm{Mn}$ and $\mathrm{Pb}$ solubility decreases with increasing dust load in Mediterranean rain samples (Theodosi et al., 2010), suggesting that this estimation could be a maximum flux for such a deposition event. However, recent studies from aerosol collected in Atlantic Ocean showed that Co and Mn solubility were little affected by dust load in contrast to Fe (Baker et al., 2020). The impact of rain inputs on TM marine stocks is also controlled by MLD fluctuations, which we ignored in this work by using a fixed ML depth at FAST and ION. As the variability of this MLD (7-21 m during the cruise, typical of the Mediterranean thermal stratified period) could change the marine budgets by a factor of 3 , we used the measured MLD (Van Wambeke et al., 2021b) at each station for calculating the TM marine stocks.

Applied to the whole transect, the atmospheric inputs obtained from our rain composition were at least 100-fold smaller than the dissolved stocks in the mixed layer, except for $\mathrm{Co}, \mathrm{Fe}$ and $\mathrm{Zn}$ (Fig. 10). The atmospheric inputs represented more than $30 \%$ of the dissolved Zn stocks and $10 \%$ to $18 \%$ of the dissolved $\mathrm{Fe}$ stocks. For Co, the maximum atmospheric fluxes estimated during the cruise represented $5 \%$ of the stocks. This significant input of $\mathrm{dFe}$ and $\mathrm{dCo}$ is in agreement with our field observations in the FAST ML. Here the comparison is based only on dissolved TMs in rainwater, yet (as discussed previously) the post-deposition processing of atmospheric particles in the water column could further enrich the marine dissolved stocks for low-solubility TMs, such as $\mathrm{Co}, \mathrm{Fe}, \mathrm{Mn}, \mathrm{Ni}, \mathrm{Pb}$ or Ti. The surface seawater could be significantly affected by the deposition of these dissolved elements in the case of wet dust deposition. In the case of the intense dust deposition event, the dissolved inputs are of the same order of magnitude as marine stocks for $\mathrm{Co}, \mathrm{Fe}, \mathrm{Mn}$, $\mathrm{Pb}$ and $\mathrm{Zn}$. The enrichment in $\mathrm{dFe}$ and $\mathrm{dMn}$ was previously observed by Wuttig et al. (2013) after artificial dust seeding in large mesocosms (simulating a wet deposition event of $10 \mathrm{~g} \mathrm{~m}^{-2}$ ). The marine TM concentrations measured during the cruise being typical of Mediterranean surface seawater concentrations, we can conclude that wet deposition events are an external supply of dissolved $\mathrm{Fe}$, Co and $\mathrm{Zn}$ for the stratified Med Sea and of all dissolved TMs during intense wet dust deposition.

\section{Conclusions}

This study provides both the dynamic properties and chemical characterization of two rain events collected in the open Med Sea concurrent with TM marine stocks in surface seawater. Our results are the only recent report of TM concentrations, EFs and fractional solubility values in rain samples collected in the remote Med Sea. By highlighting the discrepancy between TM concentrations with the previous offshore and coastal rain studies, this work demonstrates the need to provide a new and recent database of TM composition in Mediterranean rains in order to estimate the role of atmospheric TM deposition. We have shown the representativeness of Rain FAST for Saharan dust wet deposition in terms of its chemical composition and in its magnitude and extent, whereas Rain ION is more typical of an anthropogenic background rain for the remote Med Sea. On this basis, we suggest using the chemical composition of PEACETIME rains as a new reference for studies of TMs during wet deposition in the Med Sea. This study was focused on wet deposition, yet dry deposition is also an important source of TMs for surface waters in the Med Sea (Theodosi et al., 2010). As the wet deposition fluxes decreased since the 1990s due to mitigation, it is highly probable that the dry deposition fluxes were also changed. Further measurements of dry deposition in the open Med Sea are needed in order to estimate its contribution to TM atmospheric inputs.

Since atmospheric TMs have been identified as critical oligo-nutrients for the marine biosphere, it is important to study the response of the receiving waters to atmospheric inputs. This study is the first to provide in situ evidence 


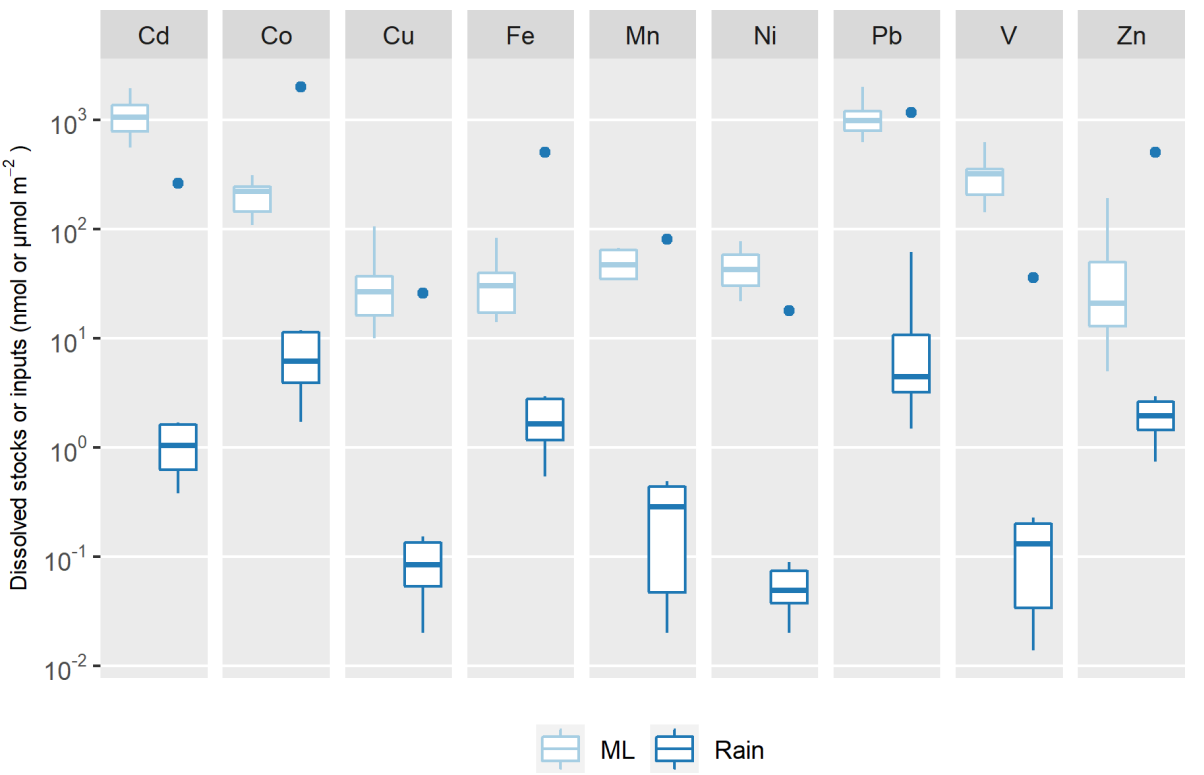

Figure 10. Comparison of marine stocks in the ML at all the stations occupied during the PEACETIME cruise (light blue boxes) with atmospheric deposition fluxes estimated from ION and FAST rains (dark blue boxes) and from an intense wet dust deposition event of $9 \mathrm{~g} \mathrm{~m}^{-2}$ (blue dots). $\mathrm{Cd}$, Co and $\mathrm{Pb}$ stocks and fluxes are given in units of $\mathrm{nmol} \mathrm{m}^{-2}$, and the other TMs are given in units of $\mu \mathrm{mol} \mathrm{m}{ }^{-2}$. For $\mathrm{Mn}$, marine stocks are derived from surface concentrations close to the coast of Corsica (OUT samples at 0,5 and $10 \mathrm{~m}$ from Wuttig et al., 2013) and in the Ionian Sea (Bannock Basin samples at 0, 10 and $15 \mathrm{~m}$ from Saager et al., 1993) as no measurements are available from the PEACETIME cruise. Boxes and whiskers as the same as in Fig. 5.

that atmospheric wet deposition constitutes a significant external source for some of these elements to surface stratified Mediterranean seawater. We recommend that the original approach developed here is used in other parts of the world where atmospheric wet deposition is thought to impact the marine biosphere, such as in HNLC (high-nutrient, low-chlorophyll) regions.

Data availability. Marine concentrations and atmospheric data used in this study are available in the biogeochemical dataset collected during the PEACETIME cruise (Guieu et al., 2020b, https://doi.org/10.17882/75747).

Supplement. The supplement related to this article is available online at: https://doi.org/10.5194/acp-22-2309-2022-supplement.

Author contributions. KD and FF designed the study and wrote the manuscript. FF, ST, JFD and ChG performed the on-board atmospheric measurements and sampling during the cruise. FF, ST and JD analysed the rain samples. MB, ATS and ARR performed the marine TM sampling and analyses. PF was the reference scientist of PEGASUS. AF and FM managed all of the technical preparation for the atmospheric sampling. PC analysed the lidar data. KD, $\mathrm{FD}$ and $\mathrm{CeG}$ designed the cruise strategy. $\mathrm{KD}$ and $\mathrm{CeG}$ coordinated the PEACETIME project. FD coordinated the ChArMEx funding request and the near-real-time forecast survey of atmospheric con- ditions during the cruise. All authors commented on the manuscript and contributed to its improvement.

Competing interests. The contact author has declared that neither they nor their co-authors have any competing interests.

Disclaimer. Publisher's note: Copernicus Publications remains neutral with regard to jurisdictional claims in published maps and institutional affiliations.

Special issue statement. This article is part of the special issue "Atmospheric deposition in the low-nutrient-low-chlorophyll (LNLC) ocean: effects on marine life today and in the future (ACP/BG inter-journal SI)". It is not associated with a conference.

Acknowledgements. The authors wish to thank Thierry Alix, the captain of the R/V Pourquoi Pas?, as well as the whole crew and technical staff for their involvement in the scientific operation. We gratefully thank Thibaut Wagener for his involvement in the trace metals clean marine sampling and Mickaël Tharaud for the HRICP-MS analysis. We thank the Leosphere technical support team and especially Alexandre Menard for their remote assistance with lidar repair under difficult offshore conditions. Hélène Ferré and the AERIS/SEDOO service are acknowledged for real-time collection during the cruise of maps from operational satellites and forecast models used in this study, with appreciated contributions 
from EUMETSAT and AERIS/ICARE for the MSG/SEVIRI products. EUMETNET is acknowledged for providing the pan-European weather radar composite images through its OPERA programme. We acknowledge the US National Oceanic and Atmospheric Administration (NOAA) Air Resources Laboratory (ARL) for the provision of the HYSPLIT (HYbrid Single-Particle Lagrangian Integrated Trajectory) model, via the NOAA ARL READY website (http://ready.arl.noaa.gov, last access: 11 February 2022), used in this publication. This study is a contribution to the PEACETIME project (http://peacetime-project.org; last access: 5 April 2021), a joint initiative of the MERMEX and ChArMEx programmes supported by CNRS-INSU, IFREMER, CEA and Météo-France as part of the decadal meta-programme MISTRALS coordinated by CNRS-INSU. PEACETIME was endorsed as a process study by GEOTRACES and is also a contribution to IMBER and SOLAS international programmes. The authors gratefully thank Rachel Shelley and the anonymous reviewer for their useful comments and critiques that have contributed to improving the manuscript.

Review statement. This paper was edited by Leiming Zhang and reviewed by Rachel Shelley and one anonymous referee.

\section{References}

Al-Momani, I. F., Aygun, S., and Tuncel, G.: Wet Deposition of Major Ions and TMs in the Eastern Mediterranean Basin, J. Geophys. Res.-Atmos., 103, 8287-8299, https://doi.org/10.1029/97JD03130, 1998.

Amato, F., Alastuey, A., Karanasiou, A., Lucarelli, F., Nava, S., Calzolai, G., Severi, M., Becagli, S., Gianelle, V. L., Colombi, C., Alves, C., Custódio, D., Nunes, T., Cerqueira, M., Pio, C., Eleftheriadis, K., Diapouli, E., Reche, C., Minguillón, M. C., Manousakas, M.-I., Maggos, T., Vratolis, S., Harrison, R. M., and Querol, X.: AIRUSE-LIFE+: a harmonized PM speciation and source apportionment in five southern European cities, Atmos. Chem. Phys., 16, 3289-3309, https://doi.org/10.5194/acp16-3289-2016, 2016.

Annett, A. L., Lapi, S., Ruth, T. J., and Maldonado, M. T.: The effects of $\mathrm{Cu}$ and $\mathrm{Fe}$ availability on the growth and $\mathrm{Cu}: \mathrm{C}$ ratios of marine diatoms, Limnol. Oceanogr., 53, 2451-2461, https://doi.org/10.4319/lo.2008.53.6.2451, 2008.

Avila, A., Queralt Mitjans, I., and Alarcón, M.: Mineralogical composition of African dust delivered by red rains over northeastern Spain, J. Geophys. Res.-Atmos., 102, 21977-21996, https://doi.org/10.1029/97JD00485, 1997.

Baconnais, I., Rouxel, O., Dulaquais, G., and Boye, M.: Determination of the copper isotope composition of seawater revisited: A case study from the Mediterranean Sea, Chem. Geol., 511, 465480, https://doi.org/10.1016/j.chemgeo.2018.09.009, 2019.

Baker, A. R., Adams, C., Bell, T. G., Jickells, T. D., and Ganzeveld, L., Estimation of atmospheric nutrient inputs to the Atlantic Ocean from $50^{\circ} \mathrm{N}$ to $50^{\circ} \mathrm{S}$ based on large-scale field sampling: Iron and other dust-associated elements, Global Biogeochem. Cy., 27, 755-767, https://doi.org/10.1002/gbc.20062, 2013.

Baker, A. R., Li, M., and Chance, R.: Trace metal fractional solubility in size-segregated aerosols from the tropical eastern At- lantic Ocean, Global Biogeochem. Cy., 34, e2019GB006510, https://doi.org/10.1029/2019GB006510, 2020.

Becagli, S., Anello, F., Bommarito, C., Cassola, F., Calzolai, G., Di Iorio, T., di Sarra, A., Gómez-Amo, J.-L., Lucarelli, F., Marconi, M., Meloni, D., Monteleone, F., Nava, S., Pace, G., Severi, M., Sferlazzo, D. M., Traversi, R., and Udisti, R.: Constraining the ship contribution to the aerosol of the central Mediterranean, Atmos. Chem. Phys., 17, 2067-2084, https://doi.org/10.5194/acp17-2067-2017, 2017.

Bergametti, G., Gomes, L., Remoudaki, E., Desbois, M., Martin, D., and Buat-Ménard, P.: Present transport and deposition patterns of African dusts to the North-Western Mediterranean, in Paleoclimatology and Paleometeorology: Modern and past patterns of global atmospheric transport, edited by: Leinen, M. and Sarnthein, M., Springer, Dordrecht, NATO ASI Ser. C, 282, 227252, https://doi.org/10.1007/978-94-009-0995-3_9, 1989.

Béthoux, J. P., Courau, P., Nicolas, E., and Ruiz-Pino, D.: Trace metal pollution in the Mediterranean Sea, Oceanol. Acta, 13, 481-488, https://archimer.ifremer.fr/doc/00103/21418/ (last access: 3 July 2021), 1990.

Bonnet, S. and Guieu, C.: Dissolution of atmospheric iron in seawater, Geophys. Res. Lett., 31, L03303, https://doi.org/10.1029/2003GL018423, 2004.

Bonnet, S. and Guieu, C.: Atmospheric forcing on the annual iron cycle in the western Mediterranean Sea: A 1-year survey, J. Geophys. Res., 111, C09010, https://doi.org/10.1029/2005JC003213, 2006.

Bove, M. C., Brotto, P., Calzolai, G., Cassola, F., Cavalli, F., Fermo, P., Hjorth, J., Massabò, D., Nava, S., Piazzalunga, A., and Schembari, C.: $\mathrm{PM}_{10}$ source apportionment applying PMF and chemical tracer analysis to ship-borne measurements in the Western Mediterranean, Atmos. Environ., 125, 140-151, https://doi.org/10.1016/j.atmosenv.2015.11.009, 2016.

Bressac, M. and Guieu, C.: Post-depositional processes: What really happens to new atmospheric iron in the ocean's surface?, Global Biogeochem. Cy., 27, 859-870, https://doi.org/10.1002/gbc.20076, 2013.

Bressac, M., Wagener, T., Leblond, N., Tovar-Sánchez, A., Ridame, C., Taillandier, V., Albani, S., Guasco, S., Dufour, A., Jacquet, S. H. M., Dulac, F., Desboeufs, K., and Guieu, C.: Subsurface iron accumulation and rapid aluminum removal in the Mediterranean following African dust deposition, Biogeosciences, 18, 6435-6453, https://doi.org/10.5194/bg-18-6435-2021, 2021.

Bruland, K. W., Franks, R. P., Knauer, G. A., and Martin, J. H.: Sampling and analytical methods for the determination of copper, cadmium, zinc, and nickel at the nanogram per liter level in sea water, Anal. Chim. Acta, 105, 233-245, https://doi.org/10.1016/S0003-2670(01)83754-5, 1979.

Buat-Ménard, P.: Particle geochemistry in the atmosphere and oceans, in: Air-Sea Exchange of Gases and Particles, edited by: Liss, P. S. and Slinn, W. G. N., NATO ASI Series C, Springer, Dordrecht, 108, 455-532, https://doi.org/10.1007/978-94-0097169-1_8, 1983.

Buat-Ménard, P. and Chesselet, R.: Variable influence of the atmospheric flux on the trace metal chemistry of oceanic suspended matter, Earth Planet. Sc. Lett., 42, 399-411, https://doi.org/10.1016/0012-821X(79)90049-9, 1979.

Chance, R., Jickells, T. D., and Baker, A. R.: Atmospheric Trace Metal Concentrations, Solubility and Deposition Fluxes in Re- 
mote Marine Air over the South-East Atlantic, Mar. Chem., 177, 45-56, https://doi.org/10.1016/j.marchem.2015.06.028, 2015.

Chazette, P., Totems, J., Ancellet, G., Pelon, J., and Sicard, M.: Temporal consistency of lidar observations during aerosol transport events in the framework of the ChArMEx/ADRIMED campaign at Minorca in June 2013, Atmos. Chem. Phys., 16, 2863 2875, https://doi.org/10.5194/acp-16-2863-2016, 2016.

Chazette, P., Flamant, C., Totems, J., Gaetani, M., Smith, G., Baron, A., Landsheere, X., Desboeufs, K., Doussin, J.-F., and Formenti, P.: Evidence of the complexity of aerosol transport in the lower troposphere on the Namibian coast during AEROCLO-sA, Atmos. Chem. Phys., 19, 14979-15005, https://doi.org/10.5194/acp-19-14979-2019, 2019.

Chester, R., Nimmo, M., and Corcoran, P. A.: Rain wateraerosol trace metal relationships at Cap Ferrat: a coastal site in the Western Mediterranean, Mar. Chem., 58, 293-312, https://doi.org/10.1016/S0304-4203(97)00056-X, 1997.

Desboeufs, K.: Trace metals and contaminants deposition, in Atmospheric Chemistry in the Mediterranean - Vol. 2, From Pollutant Sources to Impacts, edited by: Dulac, F., Sauvage, S., and Hamonou, E., Springer, Cham, Switzerland, in press, 2022.

Desboeufs, K., Losno, R., Vimeux, F., and Cholbi, S.: the $\mathrm{pH}$-dependent dissolution of wind transported Saharan dust, J. Geophys. Res., 104, 21287-21299, https://doi.org/10.1029/1999JD900236, 1999.

Desboeufs, K. V., Sofikitis, A., Losno, R., Colin, J. L., and Ausset, P.: Dissolution and solubility of trace metals from natural and anthropogenic aerosol particulate matter, Chemosphere, 58, 195203, https://doi.org/10.1016/j.chemosphere.2004.02.025, 2005.

Desboeufs, K., Leblond, N., Wagener, T., Bon Nguyen, E., and Guieu, C.: Chemical fate and settling of mineral dust in surface seawater after atmospheric deposition observed from dust seeding experiments in large mesocosms, Biogeosciences, 11, 55815594, https://doi.org/10.5194/bg-11-5581-2014, 2014.

Desboeufs, K., Bon Nguyen, E., Chevaillier, S., Triquet, S., and Dulac, F.: Fluxes and sources of nutrient and trace metal atmospheric deposition in the northwestern Mediterranean, Atmos. Chem. Phys., 18, 14477-14492, https://doi.org/10.5194/acp-1814477-2018, 2018.

Duce, R. A., Liss, P. S., Merrill, J. T., Atlas, E. L., Buat-Menard, P., Hicks, B. B., Miller, J. M., Prospero, J. M., Arimoto, R., Church, T. M., Ellis, W., Galloway, J. N., Hansen, L., Jickells, T. D., Knap, A. H., Reinhardt, K. H., Schneider, B., Soudine, A., Tokos, J. J., Tsunogai, S., Wollast, R., and Zhou, M.: The atmospheric input of trace species to the world ocean, Global Biogeochem. Cy., 5, 193-259, https://doi.org/10.1029/91GB01778, 1991.

Dulac, F.: Dynamique du transport et des retombées d'aérosols métalliques en Méditerranée occidentale, PhD Dissertation, Univ. Paris 7, 241 pp., 1986.

Dulaquais, G., Planquette, H., L'Helguen, S., Rijkenberg, M. J. A., and Boye, M.: The biogeochemistry of cobalt in the Mediterranean Sea, Global Biogeochem. Cy., 31, 377-399, https://doi.org/10.1002/2016GB005478, 2017.

Formenti, P., D'Anna, B., Flamant, C., Mallet, M., Piketh, S. J., Schepanski, K., Waquet, F., Auriol, F., Brogniez, G., Burnet, F., Chaboureau, J., Chauvigné, A., Chazette, P., Denjean, C., Desboeufs, K., Doussin, J., Elguindi, N., Feuerstein, S., Gaetani, M., Giorio, C., Klopper, D., Mallet, M. D., Nabat, P., Monod, A., Solmon, F., Namwoonde, A., Chikwililwa, C., Mushi, R., Wel- ton, E. J., and Holben, B.: The Aerosols, Radiation and Clouds in southern Africa field campaign in Namibia: Overview, illustrative observations, and way forward, B. Am. Meteorol. Soc., 100, 1277-1298, https://doi.org/10.1175/BAMS-D-17-0278.1, 2019.

Frau, F., Caboi, R., and Cristini, A.: The impact of Saharan dust on TMs solubility in rainwater in Sardinia, Italy, in: The Impact of Desert Dust Across the Mediterranean, edited by: Guerzoni, S. and Chester, R., Springer, Dordrecht, 11, 285-290, https://doi.org/10.1007/978-94-017-3354-0_28, 1996.

Fu, Y.: Étude des apports des métaux traces par le dépôt atmosphérique en Méditerranée occidentale, PhD Dissertation, Université Paris Diderot (Paris 7), 235 pp., 2018.

Fu, Y., Desboeufs, K., Vincent, J., Bon Nguyen, E., Laurent, B., Losno, R., and Dulac, F.: Estimating chemical composition of atmospheric deposition fluxes from mineral insoluble particles deposition collected in the western Mediterranean region, Atmos. Meas. Tech., 10, 4389-4401, https://doi.org/10.5194/amt10-4389-2017, 2017.

Gallisai, R., Peters, F., Volpe, G., Basart., and Baldasano J. M.: Saharan Dust deposition may affect phytoplankton growth in the Mediterranean S. Sea at ecological time scales, PLoS One, 9, e110762, https://doi.org/10.1371/journal.pone.0110762, 2014.

GEOTRACES: Intermediate Data Product Group, The GEOTRACES Intermediate Data Product 2021 (IDP2021), NERC EDS British Oceanographic Data Centre NOC [data set], https://doi.org/10.5285/cf2d9ba9-d51d-3b7c-e0538486abc0f5fd, 2021.

Gonzalez, L. and Briottet, X.: North Africa and Saudi Arabia day/night sandstorm survey (NASCube), Remote Sens., 9, 896, https://doi.org/10.3390/rs9090896, 2017.

Guerzoni, S., Molinaroli, E., Rossini, P., Rampazzo, G., Quarantotto, G., and Cristini, S.: Role of desert aerosol in metal fluxes in the Mediterranean area, Chemosphere, 39, 229-246, https://doi.org/10.1016/S0045-6535(99)00105-8, 1999.

Guieu, C. and Ridame, C.: Impact of atmospheric deposition on marine chemistry and biogeochemistry, in: Atmospheric Chemistry in the Mediterranean - Vol. 2, From Air Pollutant Sources to Impacts, edited by: Dulac, F., Sauvage, S., and Hamonou, E., Springer, Cham, Switzerland, in press, 2022.

Guieu, C., Chester, R., Nimmo, M., Martin, J. M., Guerzoni, S., Nicolas, E., Mateu, J., and Keyse, S.: Atmospheric input of dissolved and particulate metals to the North Western Mediterranean, Deep-Sea Res. Pt. II, 44, 655-674, https://doi.org/10.1016/S0967-0645(97)88508-6, 1997.

Guieu, C., Loye-Pilot, M. D., Ridame, C., and Thomas, C.: Chemical Characterization of the Saharan dust endmember: Some biogeochemical implications for the Western Mediterranean Sea, J. Geophys. Res., 107, 4258 , https://doi.org/10.1029/2001JD000582, 2002.

Guieu, C., Bonnet, S., Wagener, T., and Loÿe-Pilot, M.D.: Biomass burning as a source of dissolved iron to the open ocean?, Geophys. Res. Lett., 32, L19608, https://doi.org/10.1029/2005GL022962, 2005.

Guieu, C., Loÿe-Pilot, M.-D., Benyahya, L., and Dufour, A.: Spatial variability of atmospheric fluxes of metals (Al, $\mathrm{Fe}, \mathrm{Cd}, \mathrm{Zn}$ and $\mathrm{Pb}$ ) and phosphorus over the whole Mediterranean from a one-year monitoring experiment: Biogeochemical implications, Mar. Chem., 120, 164-178, https://doi.org/10.1016/j.marchem.2009.02.004, 2010. 
Guieu, C., D’Ortenzio, F., Dulac, F., Taillandier, V., Doglioli, A., Petrenko, A., Barrillon, S., Mallet, M., Nabat, P., and Desboeufs, K.: Introduction: Process studies at the air-sea interface after atmospheric deposition in the Mediterranean Sea - objectives and strategy of the PEACETIME oceanographic campaign (May-June 2017), Biogeosciences, 17, 5563-5585, https://doi.org/10.5194/bg-17-5563-2020, 2020a.

Guieu, C., Desboeufs, K., Albani, S., Alliouane, S., Aumont, O., Barbieux, M., Barrillon, S., Baudoux, A.-C., Berline, L., Bhairy, N., Bigeard, E., Bloss, M., Bressac, M., Brito, J., Carlotti, F., de Liege, G., Dinasquet, J., Djaoudi, K., Doglioli, A., D’Ortenzio, F., Doussin, J.-F., Duforet, L., Dulac, F., Dutay, J.-C., Engel, A., Feliu-Brito, G., Ferre, H., Formenti, P., Fu, F., Garcia, D., Garel, M., Gazeau, F., Giorio, C., Gregori, G., Grisoni, J.-M., Guasco, S., Guittonneau, J., Haëntjens, N., Heimburger, L.-E., Helias, S., Jacquet, S., Laurent, B., Leblond, N., Lefevre, D., Mallet, M., Marañón, E., Nabat, P., Nicosia, A., Obernosterer, I., Perez, L. M., Petrenko, A., Pulido-Villena, E., Raimbault, P., Ridame, C., Riffault, V., Rougier, G., Rousselet, L., Roy-Barman, M., SaizLopez, A., Schmechtig, C., Sellegri, K., Siour, G., Taillandier, V., Tamburini, C., Thyssen, M., Tovar-Sanchez, A., Triquet, S., Uitz, J., Van Wambeke, F., Wagener, T., and Zaencker, B.: Biogeochemical dataset collected during the PEACETIME cruise, SEANOE [data set], https://doi.org/10.17882/75747, 2020b.

Hardy, J. T.:. The sea surface microlayer: biology, chemistry and anthropogenic enrichment, Prog. Oceanogr., 11, 307-328, https://doi.org/10.1016/0079-6611(82)90001-5, 1982.

Heimburger, A., Losno, R., Triquet, S., Dulac F., and Mahowald, N. M.: Direct measurements of atmospheric iron, cobalt and aluminium-derived dust deposition at Kerguelen Islands, Global Biogeochem. Cy., 26, GB4016, https://doi.org/10.1029/2012GB004301, 2012.

Heimburger, A., Losno, R., and Triquet, S.: Solubility of iron and other trace elements in rainwater collected on the Kerguelen Islands (South Indian Ocean), Biogeosciences, 10, 6617-6628, https://doi.org/10.5194/bg-10-6617-2013, 2013.

Hersbach, H., Bell, B., Berrisford, P., Biavati, G., Horányi, A., Muñoz Sabater, J., Nicolas, J., Peubey, C., Radu, R., Rozum, I., Schepers, D., Simmons, A., Soci, C., Dee, D., and Thépaut, J.-N.: ERA5 hourly data on single levels from 1979 to present, Copernicus Climate Change Service (C3S) Climate Data Store (CDS) [data set], https://doi.org/10.24381/cds.adbb2d47, 2018.

Herut, B., Krom, M. D., Pan, G., and Mortimer, R.: Atmospheric input of nitrogen and phosphorus to the Southeast Mediterranean: Sources, ?uxes, and possible impact, Limnol. Oceanogr., 44, 1683-1692, https://doi.org/10.4319/lo.1999.44.7.1683, 1999.

Hydes, D. J. and Liss, P. S.: Fluorimetric method for the determination of low concentrations of dissolved aluminium in natural waters, Analyst, 101, 922-931, 1976.

Izquierdo, R., Benítez-Nelson, C. R., Masqué, P., Castillo, S., Alastuey, A., Castillo, S., Alastuey, A., and Avila, A.: Atmospheric phosphorus deposition in a near-coastal rural site in the NE Iberian Peninsula and its role in marine productivity, Atmos. Environ., 49, 361-370, https://doi.org/10.1016/j.atmosenv.2011.11.007, 2012.

Izquieta-Rojano, S., Garciìa-Gomez, H., Aguillaume, L., Santamaría, J. M., Tang, Y. S., Santamaría, C., Valiño, F., Lasheras, E., Alonso, R., Àvila, A., Cape, J. N., and Elustondo, D.: Throughfall and bulk deposition of dissolved organic nitrogen to holm oak forests in the Iberian Peninsula: flux estimation and identification of potential sources, Environ. Pollut., 210, 104-112, https://doi.org/10.1016/j.envpol.2015.12.002, 2016.

Jickells, T. D., Baker, A. R., and Chance, R.: Atmospheric transport of trace elements and nutrients to the oceans, Philos. T. R. Soc. A, 374, 20150286, https://doi.org/10.1098/rsta.2015.0286, 2016.

Jordi, A., Basterretxea, G., Tovar-Sánchez, A., Alastuey, A., and Querol, X.: Copper aerosols inhibit phytoplankton growth in the Mediterranean Sea, P. Natl. Acad. Sci. USA, 109, 21246-21249, https://doi.org/10.1073/pnas.1207567110, 2012.

Journet, E., Desboeufs, K. V., Caquineau, S., and Colin, J.-L.: Mineralogy as a critical factor of dust iron solubility, Geophys. Res. Lett., 35, L07805, https://doi.org/10.1029/2007GL031589, 2008.

Kanakidou, M., Mihalopoulos, N., Kindap, T., Im, U., Vrekoussis, M., Gerasopoulos, E., Dermitzaki, E., Unal, A., Koçak, M., Markakis, K., Melas, D., Kouvarakis, G., Youssef, A. F., Richter, A., Hatzianastassiou, N., Hilboll, A., Ebojie, F., Wittrock, F., von Savigny, C., Burrows, J. P., Ladstaetter-Weissenmayer, A., and Moubasher, H.: Megacities as hot spots of air pollution in the East Mediterranean, Atmos. Environ., 45, 1223-1235, https://doi.org/10.1016/j.atmosenv.2010.11.048, 2011.

Kanellopoulou, E. A.: Determination of heavy metals in wet deposition of Athens, Global NEST J., 3, 45-50, https://doi.org/10.30955/gnj.000181, 2001.

Longo, A. F., Ingall, E. D., Diaz, J. M., Oakes, M., King, L. E., Nenes, A., Mihalopoulos, N., Violaki, K., Avila, A., Benitez-Nelson, C. R., Brandes, J., McNulty, I., and Vine, D. J.: P-NEXFS analysis of aerosol phosphorus delivered to the Mediterranean Sea, Geophys. Res. Lett., 41, 4043-4049, https://doi.org/10.1002/2014GL060555, 2014.

Losno, R.: Chimie d'éléments minéraux en traces dans les pluies méditerranéennes, $\mathrm{PhD}$ thesis, Univ. Paris-Diderot de Paris 7, https://tel.archives-ouvertes.fr/tel-00814327/document (last access: 4 July 2021), 1989.

Loÿe-Pilot, M.-D. and Martin, J. M.: Saharan dust input to the western Mediterranean: an eleven years record in Corsica, in: The Impact of Desert Dust Across the Mediterranean, edited by: Guerzoni, S. and Chester, R., Springer, Dordrecht, 11, 191-199, https://doi.org/10.1007/978-94-017-3354-0_18, 1996.

Mackey, K. R. M., Buck, K. N., Casey, J. R., Cid, A., Lomas, M. W., Sohrin, Y., and Paytan, A.: Phytoplankton Responses to Atmospheric Metal Deposition in the Coastal and Open-Ocean Sargasso Sea, Front. Microbiol., 3, 359, https://doi.org/10.3389/fmicb.2012.00359, 2012.

Mallet, M. D., D’Anna, B., Même, A., Bove, M. C., Cassola, F., Pace, G., Desboeufs, K., Di Biagio, C., Doussin, J.-F., Maille, M., Massabò, D., Sciare, J., Zapf, P., di Sarra, A. G., and Formenti, P.: Summertime surface $\mathrm{PM}_{1}$ aerosol composition and size by source region at the Lampedusa island in the central Mediterranean Sea, Atmos. Chem. Phys., 19, 11123-11142, https://doi.org/10.5194/acp-19-11123-2019, 2019.

Markaki, Z., Loëe-Pilot, M. D., Violaki, K., Benyahya, L., and Mihalopoulos, N.: Variability of atmospheric deposition of dissolved nitrogen and phosphorus in the Mediterranean and possible link to the anomalous seawater N/P ratio, Mar. Chem., 120, 187-194, https://doi.org/10.1016/j.marchem.2008.10.005, 2010.

Migon, C., Robin, T., Dufour, A., and Gentili, B.: Decrease of lead concentrations in the Western Mediterranean atmo- 
sphere during the last 20 years, Atmos. Environ., 42, 815-821, https://doi.org/10.1016/j.atmosenv.2007.10.078, 2008.

Migon, C., Heimbürger-Boavida, L.-E., Dufour, A., Chiffoleau, J.-F., and Cossa, D.: Temporal variability of dissolved trace metals at the DYFAMED time-series station, Northwestern Mediterranean, Mar. Chem., 225, 103846, https://doi.org/10.1016/j.marchem.2020.103846, 2020.

Millero, F. J.: Chemical Oceanography, 4th Edn., CRC Press, https://doi.org/10.1201/b14753, 2013.

Morel, F. M. M., Hudson, R. J. M., and Price, N. M: Limitation of productivity by trace metals in the sea, Limnol. Oceanogr., 36, 1742-1755, https://doi.org/10.4319/lo.1991.36.8.1742, 1991.

Morel, F. M., Milligan, A. J., and Saito, M. A.: Marine bioinorganic chemistry: the role of trace metals in the oceanic cycles of major nutrients, Treatise Geochem., 6, 625, https://doi.org/10.1016/B008-043751-6/06108-9, 2003.

Morin, E., Krajeski, W. F., Goorich, D. C., Gao, X., and Sorooshian, S.: Estimating rainfall intensities from weather radar data: The scale-dependency problem, J. Hydrometeorol., 4, 782-797, https://doi.org/10.1175/15257541(2003)004<0782:ERIFWR>2.0.CO;2, 2003.

Morley, N. H., Burton, J. D., Tankere, S. P. C., and Martin, J.-M.: Distribution and behaviour of some dissolved trace metals in the western Mediterranean Sea, Deep-Sea Res. Pt. II, 44, 675-691, https://doi.org/10.1016/S0967-0645(96)00098-7, 1997.

Nehir, M. and Koçak, M.: Atmospheric water-soluble organic nitrogen (WSON) in the eastern Mediterranean: origin and ramifications regarding marine productivity, Atmos. Chem. Phys., 18, 3603-3618, https://doi.org/10.5194/acp-18-3603-2018, 2018.

Noble, A. E., Saito, M. A., Maiti, K., and Benitez-Nelson, C.: Cobalt, manganese, and iron near the Hawaiian Islands: A potential concentrating mechanism for cobalt within a cyclonic eddy and implications for the hybridtype trace metals, Deep-Sea Res. Pt. II, 55, 1473-1490, https://doi.org/10.1016/j.dsr2.2008.02.010, 2008.

Ochoa-Hueso, R., Allen, E. B., Branquinho, C., Cruz, C., Dias, T., Fenn, M. E., Manrique, E., Perez-Corona, M. E., Sheppard, L. J., and Stock, W. D.: Nitrogen deposition effects on Mediterraneantype ecosystems: an ecological assessment, Environ. Pollut., 159, 2265-2279, https://doi.org/10.1016/j.envpol.2010.12.019, 2011.

OSPAR Commission: Atmospheric deposition of selected heavy metals and persistent organic pollutants to the OSPAR maritime area (1990-2005). Publication 375/2008, 2008.

Özsoy, T. and Örnektekin, S.: TMs in Urban and Suburban Rainfall, Mersin, Northeastern Mediterranean, Atmos. Res., 94, 203-219, https://doi.org/10.1016/j.atmosres.2009.05.017, 2009.

Pacyna, E. G., Pacyna, J. M., Fudala, J., Strzelecka-Jastrzab, E., Hlawiczka, S., Panasiuk, D., Nitter, S., Pregger, T., Pfeiffer, H., and Friedrich, R.: Current and future emissions of selected heavy metals to the atmosphere from anthropogenic sources in Europe, Atmos. Environ., 41, 8557-8566, https://doi.org/10.1016/j.atmosenv.2007.07.040, 2007.

Paris, R. and Desboeufs, K. V.: Effect of atmospheric organic complexation on iron-bearing dust solubility, Atmos. Chem. Phys., 13, 4895-4905, https://doi.org/10.5194/acp-134895-2013, 2013.

Pinedo-González, P., Joshua West, A., Tovar-Sánchez, A., Duarte, C. M., Marañón, E., Cermeño, P., González, N., Sobrino, C., Huete-Ortega, M., Fernández, A., López-Sandoval, D. C., Vi- dal, M., Blasco, D., Estrada, M., and Sañudo-Wilhelmy, S. A.: Surface distribution of dissolved trace metals in the oligotrophic ocean and their influence on phytoplankton biomass and productivity, Global. Biogeochem. Cy., 29, 1763-1781, https://doi.org/10.1002/2015GB005149, 2015.

Powell, C. F., Baker, A. R., Jickells, T. D., Bange, H. W., Chance, R. J., and Yodle, C.: Estimation of the atmospheric flux of nutrients and trace metals to the eastern tropical North Atlantic Ocean, J. Atmos. Sci., 72, 4029-4045, https://doi.org/10.1175/JAS-D-150011.1, 2015.

Pulido-Villena, E., Rérolle, V., and Guieu, C.: Transient fertilizing effect of dust in P-deficient LNLC surface ocean, Geophys. Res. Lett., 37, L01603, https://doi.org/10.1029/2009GL041415, 2010.

Pulido-Villena, E., Desboeufs, K., Djaoudi, K., Van Wambeke, F., Barrillon, S., Doglioli, A., Petrenko, A., Taillandier, V., Fu, F., Gaillard, T., Guasco, S., Nunige, S., Triquet, S., and Guieu, C.: Phosphorus cycling in the upper waters of the Mediterranean Sea (PEACETIME cruise): relative contribution of external and internal sources, Biogeosciences, 18, 5871-5889, https://doi.org/10.5194/bg-18-5871-2021, 2021.

Rahn, K. A.: The Chemical Composition of the Atmospheric Aerosol, Tech. Rept., Graduate School of Oceanography, Univ. Rhode Island, Kingston, RI, 265 pp., https://books.google.fr/ books?id=_q-dOAQAAMAAJ (last access: 4 July 2021), 1976.

Raut, J.-C. and Chazette, P.: Assessment of vertically-resolved $\mathrm{PM}_{10}$ from mobile lidar observations, Atmos. Chem. Phys., 9, 8617-8638, https://doi.org/10.5194/acp-9-8617-2009, 2009.

Richon, C., Dutay, J.-C., Dulac, F., Wang, R., and Balkanski, Y.: Modeling the biogeochemical impact of atmospheric phosphate deposition from desert dust and combustion sources to the Mediterranean Sea, Biogeosciences, 15, 2499-2524, https://doi.org/10.5194/bg-15-2499-2018, 2018a.

Richon, C., Dutay, J. C., Dulac, F., Wang, R., Balkanski, Y., Nabat, P., Aumont, O., Desboeufs, K., Laurent, B., Guieu, C., and Raimbault, P.: Modeling the impacts of atmospheric deposition of nitrogen and desert dust-derived phosphorus on nutrients and biological budgets of the Mediterranean Sea, Prog. Oceanogr., 163, 21-39, https://doi.org/10.1016/j.pocean.2017.04.009, 2018b.

Ridame, C., Le Moal, M., Guieu, C., Ternon, E., Biegala, I. C., L'Helguen, S., and Pujo-Pay, M.: Nutrient control of $\mathrm{N}_{2}$ fixation in the oligotrophic Mediterranean Sea and the impact of Saharan dust events, Biogeosciences, 8, 2773-2783, https://doi.org/10.5194/bg-8-2773-2011, 2011.

Royer, P., Chazette, P., Lardier, M., and Sauvage, L.: Aerosol content survey by mini N2-Raman lidar: Application to local and long-range transport aerosols, Atmos. Environ., 45, 7487-7495, https://doi.org/10.1016/j.atmosenv.2010.11.001, 2011.

Rudnick, R. L. and Gao, S.: Composition of the Continental Crust. in: Treatise on Geochemistry, edited by: Holland, H. D. and Turekian, K. K., Elsevier, Amsterdam, 3, 1-64, 2003.

Saager, P. M., Schijf, J., and de Baar, H. J. W.: Trace-metal distributions in seawater and anoxic brines in the eastern Mediterranean Sea, Geochim. Cosmochim. Ac., 57, 1419-1432, https://doi.org/10.1016/0016-7037(93)90003-F, 1993.

Sandroni, V. and Migon, C.: Atmospheric deposition of metallic pollutants over the Ligurian Sea: labile and residual inputs, Chemosphere, 47, 753-764, https://doi.org/10.1016/s00456535(01)00337-x, 2002. 
Saltikoff, E., Haase, G., Delobbe, L., Gaussiat, N., Martet, M., Idziorek, D., Leijnse, H., Novák, P., Lukach, M., and Stephan, K.: OPERA the Radar Project, Atmosphere, 10, 320, https://doi.org/10.3390/atmos10060320, 2019.

Sciare, J., Bardouki, H., Moulin, C., and Mihalopoulos, N.: Aerosol sources and their contribution to the chemical composition of aerosols in the Eastern Mediterranean Sea during summertime, Atmos. Chem. Phys., 3, 291-302, https://doi.org/10.5194/acp-3291-2003, 2003.

Sedwick, P. N., Sholkovitz, E. R., and Church, T. M.: Impact of anthropogenic combustion emissions on the fractional solubility of aerosol iron: Evidence from the Sargasso Sea, Geochem. Geophy. Geosy., 8, Q10Q06, https://doi.org/10.1029/2007GC001586.

Sherrell, R. M. and Boyle, E. A.: Zinc, chromium, vanadium and iron in the Mediterranean Sea, Deep-Sea Res. Pt. A, 35, 13191334, https://doi.org/10.1016/0198-0149(88)90085-4, 1988.

Smedley, P. L. and Kinniburgh, D. G.: Molybdenum in natural waters: A review of occurrence, distributions and controls, Appl. Geochem., 84, 387-432, https://doi.org/10.1016/j.apgeochem.2017.05.008, 2017.

Taillandier, V., Prieur, L., D’Ortenzio, F., Ribera d'Alcalà, M., and Pulido-Villena, E.: Profiling float observation of thermohaline staircases in the western Mediterranean Sea and impact on nutrient fluxes, Biogeosciences, 17, 3343-3366, https://doi.org/10.5194/bg-17-3343-2020, 2020.

Ternon, E., Guieu, C., Loÿe-Pilot, M.-D., Leblond, N., Bosc, E., Gasser, B., Miquel, J.-C., and Martín, J.: The impact of Saharan dust on the particulate export in the water column of the North Western Mediterranean Sea, Biogeosciences, 7, 809-826, https://doi.org/10.5194/bg-7-809-2010, 2010.

The Mermex Group: Marine ecosystems' responses to climatic and anthropogenic forcings in the Mediterranean, Prog. Oceanogr., 91, 97-166, https://doi.org/10.1016/j.pocean.2011.02.003, 2011.

Theodosi, C., Markaki, Z., Tselepides, A., and Mihalopoulos, N.: The significance of atmospheric inputs of soluble and particulate major and TMs to the Eastern Mediterranean Sea, Mar. Chem., 120, 154-163, https://doi.org/10.1016/J.MARCHEM.2010.02.003, 2010.

Thieuleux, F., Moulin, C., Bréon, F. M., Maignan, F., Poitou, J., and Tanré, D.: Remote sensing of aerosols over the oceans using MSG/SEVIRI imagery, Ann. Geophys., 23, 3561-3568, https://doi.org/10.5194/angeo-23-3561-2005, 2005.

Tovar-Sánchez, A., Arrieta, J. M., Duarte, C. M., and SañudoWilhelmy, S. A.: Spatial gradients in trace metal concentrations in the surface microlayer of the Mediterranean Sea, Front. Mar. Sci., 1, 79, https://doi.org/10.3389/fmars.2014.00079, 2014.

Tovar-Sánchez, A., Rodríguez-Romero, A., Engel, A., Zäncker, B., Fu, F., Marañón, E., Pérez-Lorenzo, M., Bressac, M., Wagener, T., Triquet, S., Siour, G., Desboeufs, K., and Guieu, C.: Characterizing the surface microlayer in the Mediterranean Sea: trace metal concentrations and microbial plankton abundance, Biogeosciences, 17, 2349-2364, https://doi.org/10.5194/bg-172349-2020, 2020.

Travnikov, O., Ilyin, I., Rozovskaya, O., Varygina, M., Aas, W., Uggerud, H. T., Mareckova, K., and Wankmueller, R.: Long-term Changes of Heavy Metal Transboundary Pollution of the Environment (1990-2010), EMEP Status Report 2/2012, 2012.
Van Wambeke, F., Pulido, E., Catala, P., Dinasquet, J., Djaoudi, K., Engel, A., Garel, M., Guasco, S., Marie, B., Nunige, S., Taillandier, V., Zäncker, B., and Tamburini, C.: Spatial patterns of ectoenzymatic kinetics in relation to biogeochemical properties in the Mediterranean Sea and the concentration of the fluorogenic substrate used, Biogeosciences, 18, 2301-2323, https://doi.org/10.5194/bg-18-2301-2021, 2021a.

Van Wambeke, F., Taillandier, V., Desboeufs, K., Pulido-Villena, E., Dinasquet, J., Engel, A., Marañón, E., Ridame, C., and Guieu, C.: Influence of atmospheric deposition on biogeochemical cycles in an oligotrophic ocean system, Biogeosciences, 18, 5699-5717, https://doi.org/10.5194/bg-18-5699-2021, 2021b.

Vincent, J., Laurent, B., Losno, R., Bon Nguyen, E., Roullet, P., Sauvage, S., Chevaillier, S., Coddeville, P., Ouboulmane, N., di Sarra, A. G., Tovar-Sánchez, A., Sferlazzo, D., Massanet, A., Triquet, S., Morales Baquero, R., Fornier, M., Coursier, C., Desboeufs, K., Dulac, F., and Bergametti, G.: Variability of mineral dust deposition in the western Mediterranean basin and south-east of France, Atmos. Chem. Phys., 16, 8749-8766, https://doi.org/10.5194/acp-16-8749-2016, 2016.

Violaki, K., Bourrin, F., Aubert, D., Kouvarakis, G., Delsaut, N., and Mihalopoulos, N.: Organic phosphorus in atmospheric deposition over the Mediterranean Sea: An important missing piece of the phosphorus cycle, Prog. Oceanogr., 163, 50-58, https://doi.org/10.1016/j.pocean.2017.07.009, 2018.

Wagener, T., Pulido-Villena, E., and Guieu, C.: Dust iron dissolution in seawater: Results from a one-year time-series in the Mediterranean Sea, Geophys. Res. Lett., 35, L16601, https://doi.org/10.1029/2008GL034581, 2008.

Wagener, T., Guieu, C., and Leblond, N.: Effects of dust deposition on iron cycle in the surface Mediterranean Sea: results from a mesocosm seeding experiment, Biogeosciences, 7, 3769-3781, https://doi.org/10.5194/bg-7-3769-2010, 2010.

Weinzierl, B., Ansmann, A., Prospero, J. M., Althausen, D., Benker, N., Chouza, F., Dollner, M., Farrell, D., Fomba, W. K., Freudenthaler, V., Gasteiger, J., Groß, S., Haarig, M., Heinold, B., Kandler, K., Kristensen, T. B., Mayol-Bracero, O. L., Müller, T., Reitebuch, O., Sauer, D., Schäfler, A., Schepanski, K., Spanu, A., Tegen, I., Toledano, C., and Walser, A.: The Saharan Aerosol Long-Range Transport and Aerosol-Cloud-Interaction Experiment: Overview and Selected Highlights, B. Am. Meteorol. Soc., 98, 1427-1451, https://doi.org/10.1175/BAMS-D-15$00142.1,2017$.

Wuttig, K., Wagener, T., Bressac, M., Dammshäuser, A., Streu, P., Guieu, C., and Croot, P. L.: Impacts of dust deposition on dissolved trace metal concentrations ( $\mathrm{Mn}, \mathrm{Al}$ and $\mathrm{Fe}$ ) during a mesocosm experiment, Biogeosciences, 10, 2583-2600, https://doi.org/10.5194/bg-10-2583-2013, 2013.

Ye, Y., Wagener, T., Völker, C., Guieu, C., and Wolf-Gladrow, D. A.: Dust deposition: iron source or sink? A case study, Biogeosciences, 8, 2107-2124, https://doi.org/10.5194/bg-8-21072011, 2011.

Yoon, Y. Y., Martin, J.-M., and Cotté, M. H.: Dissolved trace metals in the western Mediterranean Sea: total concentration and fraction isolated by C18 Sep-Pak technique, Mar. Chem., 66, 129148, https://doi.org/10.1016/S0304-4203(99)00033-X, 1999. 